\title{
G1/S Cell Cycle Blockers and Inhibitors of Cyclin-Dependent Kinases Suppress Camptothecin-Induced Neuronal Apoptosis
}

\author{
David S. Park, ${ }^{1}$ Erick J. Morris, ${ }^{2}$ Lloyd A. Greene, ${ }^{1}$ and Herbert M. Geller ${ }^{2}$ \\ ${ }^{1}$ Department of Pathology and Center for Neurobiology and Behavior, Columbia University College of Physicians and \\ Surgeons, New York, New York 10032, and '2Department of Pharmacology, University of Medicine and Dentistry of New \\ Jersey-Robert Wood Johnson Medical School, Piscataway, New Jersey 08854
}

Previous studies have demonstrated that G1/S cell cycle blockers and inhibitors of cyclin-dependent kinases (CDKs) prevent the death of nerve growth factor (NGF)-deprived PC12 cells and sympathetic neurons, suggesting that proteins normally involved in the cell cycle may also serve to regulate neuronal apoptosis. Past findings additionally demonstrate that DNAdamaging agents, such as the DNA topoisomerase (topo-I) inhibitor camptothecin, also induce neuronal apoptosis. In the present study, we show that camptothecin-induced apoptosis of PC12 cells, sympathetic neurons, and cerebral cortical neurons is suppressed by the G1/S blockers deferoxamine and mimosine, as well as by the CDK-inhibitors flavopiridol and olomoucine. In each case, the $\mathrm{IC}_{50}$ values were similar to those reported for inhibition of death induced by NGF-deprivation. In contrast, other agents that arrest DNA synthesis, such as aphidicolin and $N$-acetylcysteine, failed to block death. This suggests that the inhibition of DNA synthesis per se is insufficient to provide protection from camptothecin. We find additionally that the cysteine aspartase family protease inhibitor zVAD-fmk inhibits apoptosis evoked by NGF-deprivation but not camptothecin treatment. Thus, despite their shared sensitivity to G1/S blockers and CDK inhibitors, the apoptotic pathways triggered by these two causes of death diverge at the level of the cysteine aspartase. In summary, neuronal apoptosis induced by the DNA-damaging agent camptothecin appears to involve signaling pathways that normally control the cell cycle. The consequent death signals of such deregulation, however, are different from those that result from trophic factor deprivation.

Key words: cell cycle; apoptosis; cyclin-dependent kinases; camptothecin; DNA damage; cysteine proteases
Neuronal apoptosis is an integral part of nervous system development (Oppenheim, 1991) as well as neuronal injury and disease (Cheng and Mattson, 1991). However, the signaling mechanisms that regulate this pathway are poorly understood. Characterization of apoptosis in neuronal cells deprived of trophic support has provided some insight into possible mechanisms by which death may occur. For example, neuronal apoptosis is accompanied by changes in cyclin-dependent kinase (CDK) activity and cyclin expression (Brooks et al., 1993; Freeman et al., 1994; Gao and Zalenka, 1995), suggesting that proteins normally involved in cell cycle control might also serve to regulate neuronal death. Consistent with this, several agents that inhibit cell cycle progression, including chlorophenylthio-cAMP (CPT-cAMP) (Rydel and Greene, 1988; Farinelli and Greene, 1996); N-acetylcysteine (NAC) (Ferrari et al., 1995; Yan et al., 1995); the G1/S blockers mimosine, deferoxamine, and ciclopirox (but not S- and M-phase blockers) (Farinelli and Greene, 1996); and the CDK inhibitors flavopiridol and olomoucine (Park et al., 1996a), promote survival of neuronal PC12 cells and sympathetic neurons deprived of

Received July 15, 1996; revised Sept. 24, 1996; accepted Dec. 3, 1996.

This work was supported in part by grants from National Institutes of Health (NIH; NS33689), the March of Dimes, the Blanchette Rockefeller Foundation, the Amyotrophic Lateral Sclerosis Foundation, and the Aaron Diamond Foundation (L.A.G.); and by NIH Grant NS25168 (H.M.G.). D.S.P. is an Aaron Diamond Foundation Fellow. We thank Dr. Peter J. Worland for kindly donating flavopiridol and for his helpful discussions.

Correspondence should be addressed to Dr. David S. Park, Department of Pathology and Center for Neurobiology and Behavior, Columbia University College of Physicians and Surgeons, 630 West 168th Street, New York, NY 10032.

D.S.P. and E.J.M. contributed equally to this work.

Copyright (C) 1997 Society for Neuroscience $0270-6474 / 97 / 171256-15 \$ 05.00 / 0$ trophic support. Accordingly, it has been hypothesized that neurotrophins may prevent neuronal death by coordinating cell cycle progression and/or preventing inappropriate activation of cell cycle signaling pathways (Batistatou and Greene, 1993; Rubin et al., 1993; Ferrari and Greene, 1994; Freeman et al., 1994; Greene et al., 1995).

Several anticancer agents, including the S-phase inhibitor cytosine arabinoside (araC) (Winkelman and Hines, 1983; Wallace and Johnson, 1989; Martin et al., 1990) and the DNA topoisomerase-II inhibitors etoposide, teniposide, and mitoxanthrone (Nakajima et al., 1994; Tomkins et al., 1994), induce neuronal apoptosis. Recently, it was demonstrated that the specific DNA topoisomerase-I (topo-I) inhibitor camptothecin also causes neuronal apoptotic death (Morris and Geller, 1996). These observations led to the proposal of a novel mechanism of action of topo-I poisons whereby transcription contributes to the formation of DNA strand breaks; this process would be similar to replicationally driven DNA strand break formation in proliferating cells (Hsiang et al., 1985, 1989). However, the downstream events that occur after camptothecin-induced apoptosis remain unclear. Recent reports demonstrate increased cdc2 (Shimizu et al., 1995) and cyclin E-associated (Ping Dou et al., 1995) kinase activities in response to DNA-damaging agents, including camptothecin. This raises the possibility that, as with neuronal death caused by trophic factor deprivation, neuronal apoptosis induced by camptothecin and other DNA-damaging agents may be attributable to deregulated or inappropriate cell cycle signals. In the present studies, we have tested this notion by assessing the capacity of various cell cycle blockers to suppress camptothecin-induced 
death in several different neuronal cell culture systems. In addition, we examined whether the consequent death signals resulting from deregulated cell cycle signals were similar in neurons induced to die by either nerve growth factor (NGF) deprivation or camptothecin treatment.

\section{MATERIALS AND METHODS}

Materials. Human recombinant NGF was kindly provided by Genentech (San Francisco, CA). Flavopiridol (L86-8275, [(-) cis-5,7-dihydroxy-2(2-chlorophenyl)-8[4-(3-hydroxy-1-methyl)-piperidinyl]-4H-benzopyran$4-1]$ ) was a generous gift from Dr. Peter J. Worland (National Cancer Institute). Olomoucine (2-(2-hydroxyethylamino)-6-benzylamino-9methylpurine) and iso-olomoucine were obtained from LC Laboratories. Actinomycin D, aphidicolin, camptothecin, 5(6)-carboxyfluorescein diacetate (CFDA), ciclopirox, 4',6-diamidino-2-phenylindole (DAPI), deferoxamine, mimosine, $N$-acetylcysteine, mouse NGF, and anti-mouse NGF antiserum were obtained from Sigma (St. Louis, MO). Chlorophenylthio (CPT)-cAMP and zVAD-fluoromethylketone (zVAD-fmk) were purchased from Boehringer Mannheim (Indianapolis, IN) and Enzyme Systems Products (Dublin, CA), respectively.

Culture and survival assay of PC12 cells. Naive PC12 cells were cultured and passaged as described previously (Greene and Tischler, 1976). Neuronally differentiated $\mathrm{PC} 12$ cells were generated by exposing PC12 cells to NGF in serum-free RPMI 1640 for $8-9$ d. For survival experiments, naive, or neuronally differentiated PC12 cells were plated onto collagencoated 24-well tissue culture dishes at a density of $\sim 2 \times 10^{5}$ cells per well. PC12 cells were cultured in serum ( $10 \%$ heat-inactivated horse serum and $5 \%$ fetal calf serum) containing RPMI 1640 medium (naive PC12 cells) and serum-free RPMI 1640 medium containing NGF (100 ng/ml) (neuronal PC12 cells) throughout the course of the survival experiment. At appropriate times of culture under the conditions described in the text, cells were lysed and the numbers of viable cells were evaluated as described previously (Rukenstein et al., 1991). All experimental points are expressed as a percentage of cells plated on day 0 and are reported as mean $\pm \operatorname{SEM}(n=3)$.

Culture and survival assay of rat sympathetic neurons. Primary cultures of rat sympathetic neurons were obtained from dissociated superior cervical ganglia of postnatal day 1 rats (strain, Sprague Dawley) as described previously (Lee et al., 1980). The cells were plated onto collagen-coated 24-well dishes at a density of $\sim 0.5$ ganglia per well and maintained in RPMI 1640 medium supplemented with $10 \%$ heat-inactivated horse serum and $60 \mathrm{ng} / \mathrm{ml}$ mouse NGF for a period of $3 \mathrm{~d}$ before the start of camptothecin survival experiments. A mixture of uridine and 5-fluorodeoxyuridine (10 $\mu \mathrm{M}$ each) was also added to eliminate nonneuronal cells on day 2 . NGF deprivation was performed by washing with NGF-free medium and addition of anti-NGF antiserum as described previously (Park et al., 1996a). At appropriate times, the numbers of viable, phase-bright neurons were determined by strip counting as described previously (Rydel and Greene, 1988). All experimental points are expressed relative to the original number of neurons present in each well and are reported as mean $\pm \operatorname{SEM}(n=3)$.

Culture and survival assay of rat cerebral cortical neurons. Primary cultures of dissociated embryonic day 17 rat cerebral cortical neurons were obtained from timed-pregnant Sprague Dawley rats (Hilltop Lab Animals, Scottsdale, PA) and prepared by the method described previously (Ventimiglia and Geller, 1987). Neurons were plated on top of a preexisting monolayer of rat cerebral cortical astrocytes cultured from postnatal days 1-3 Sprague Dawley rats as described previously (Morrison and deVellis, 1981). For quantitative neuronal survival experiments, cortical neurons were plated at a density of $1.5 \times 10^{5}$ cells/well in 24-well plates and maintained in DMEM supplemented with $2 \%$ heat-inactivated fetal calf serum, $\mathrm{NaHCO}_{3}(2.2 \mathrm{mg} / \mathrm{ml})$, penicillin $(50 \mu \mathrm{g} / \mathrm{ml})$, and streptomycin $(50 \mathrm{U} / \mathrm{ml})$. Neuronal survival was determined using the CFDA assay (Petroski and Geller, 1994). Briefly, cells were washed once and incubated with CFDA. Under these conditions, both neurons and astrocytes take up and cleave CFDA to the anionic fluorophore 5(6)carboxyfluorescein (CF). The medium was then removed and the cells rinsed, during which time the astrocytes pump $\mathrm{CF}$ into the medium while neurons retain it for several hours. After the rinse, the cells were lysed and the fluorescence of the lysate was measured with a fluorescence spectrophotometer. Fluorescence intensity is proportional to the number of metabolically viable neurons (Petroski and Geller, 1994). Each experiment was performed at least three times and run in parallel with a standard CF calibration curve to ensure accurate fluorometric measure- ments. Neuronal survival after treatment with the pharmacological agents was compared with parallel treatment with control medium, and survival was expressed as percent of control $\pm \mathrm{SD}(n=3-4$ per condition). Camptothecin, flavopiridol, olomoucine, and iso-olomoucine were dissolved in $100 \%$ DMSO. Control cultures typically contained $<0.3 \%$ DMSO as vehicle control and were generally not toxic within the time range of the experiments described below.

Determination of apoptotic chromatin condensation. To determine the degree of apoptotic chromatin condensation, cells were grown on 12 $\mathrm{mm}$ glass coverslips, treated as described, and then fixed with ice-cold ethanol/acetic acid (95:5) for $8 \mathrm{~min}$ at $4^{\circ} \mathrm{C}$. After fixation, cells were rinsed three times in $0.1 \mathrm{M}$ PBS and incubated with $1 \mu \mathrm{g} / \mathrm{ml}$ DAPI for $10 \mathrm{~min}$ at room temperature. Cells were then rinsed three times in PBS and once in water, mounted upside down on a glass slide, and sealed with nail enamel. Nuclei were visualized under UV epifluorescence, and images were captured using a Dage CCD72 camera, Dage DSP2000 digital signal processor, and a Macintosh Quadra 700 with a Scion LG-3 frame grabber board under the control of National Institutes of Health Image program (V 1.57, available by anonymous FTP from zippy.nimh.nih.gov) and further processed with Adobe Photoshop software.

\section{RESULTS}

\section{Effects of cell cycle blockers on camptothecin-induced death of nonproliferating neuronally differentiated PC12 cells}

\section{CDK inhibitors, G1/S blockers, and CPT-cAMP inhibit camptothecin-induced death of neuronally differentiated PC12 cells}

Previous studies have demonstrated that camptothecin causes apoptotic death of rat cerebral cortical neurons (Morris and Geller, 1996). As shown in Figure $1 A$, camptothecin $(10 \mu \mathrm{M})$ is also toxic to nonproliferating neuronally differentiated PC12 cells; $50 \%$ of the cells die after $3 \mathrm{~d}$ of treatment, and nearly all are dead by $6 \mathrm{~d}$, even in the presence of NGF. DAPI staining of PC12 cell cultures treated with camptothecin shows chromatin condensation characteristic of apoptosis (Fig. 2D, arrow), whereas practically all of the nuclei in control, untreated cultures are intact (Fig. 2B). As demonstrated with cortical neurons (Morris and Geller, 1996), inhibition of transcription by actinomycin D cotreatment prevents the camptothecin-mediated death of neuronal PC12 cells (data not shown).

We determined next whether the CDK-inhibitors flavopiridol and olomoucine could prevent camptothecin-induced death of neuronally differentiated PC12 cells. Flavopiridol is a flavanoid derivative that potently inhibits cdk1, 2, and 4 activities (Losiewicz et al., 1994; Filgueira de Azevedo et al., 1996) (P.J. Worland, unpublished results), and olomoucine is a purine derivative that has been reported to inhibit cdk1, 2, and 5, as well as ERK1/ MAP-kinase activities (Vesely et al., 1994). Both agents reportedly block progression from G1 to S- and G2 to M-phases of the cell cycle (Kaur et al., 1992; Vesely et al., 1994) and are poor inhibitors of other kinases examined (Losiewitz et al., 1994; Vesely et al., 1994; Park et al., 1996a). Both drugs were quite effective in long-term protection from camptothecin-induced death. Approximately $70 \%$ of the cells were viable after $6 \mathrm{~d}$ of camptothecin treatment, whereas all cells were dead with camptothecin alone at this time (Fig. $1 A$ ). Treatment of cells with either agent alone in the absence of camptothecin also resulted in $\sim 30 \%$ cell death at day 6 (data not shown). In addition, both flavopiridol and olomoucine were able to prevent camptothecininduced apoptotic chromatin condensation (Fig. $2 F, H$ ). However, both flavopiridol and olomoucine, in combination with camptothecin or alone, were able to induce partial chromatin changes consisting of granular, punctate nuclei (Fig. $2 \mathrm{H}$, arrow- 


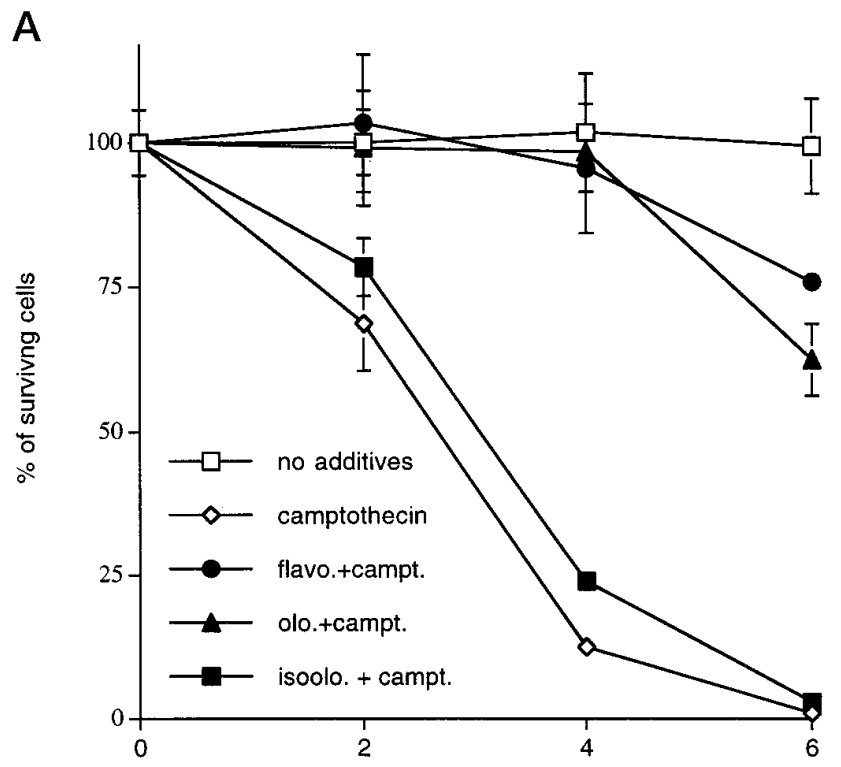

days in serum-free medium containing NGF

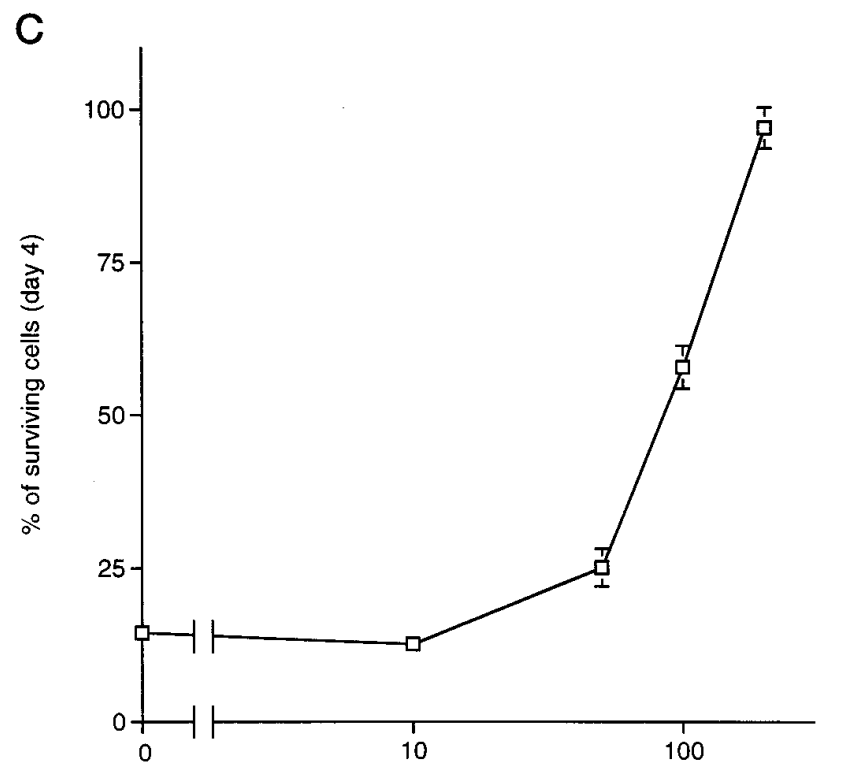

olomoucine $(\mu \mathrm{M})$

head), suggesting that these agents might have other effects on nuclear structure.

Maximal protection from death was observed at $1 \mu \mathrm{M}$ flavopiridol (Fig. 1B) and $200 \mu \mathrm{M}$ olomoucine (Fig. 1C). These are the minimum concentrations that fully inhibit DNA synthesis by proliferating PC12 cells (Park et al., 1996a). Isoolomoucine, an analog of olomoucine that differs in the location of one substituent methyl group and poorly inhibits CDK activity or DNA synthesis (Park et al., 1996a), was used as an internal control for any nonspecific effects of the olomoucine chemical moiety. It failed to prevent the death of camptothecin-treated neuronal cells (Fig. 1A). Figure 3 shows the morphology of neuronally differentiated PC12 cells treated with the CDK inhibitors in the presence or absence of camptothecin. The cells rescued by flavopiridol or olomoucine show

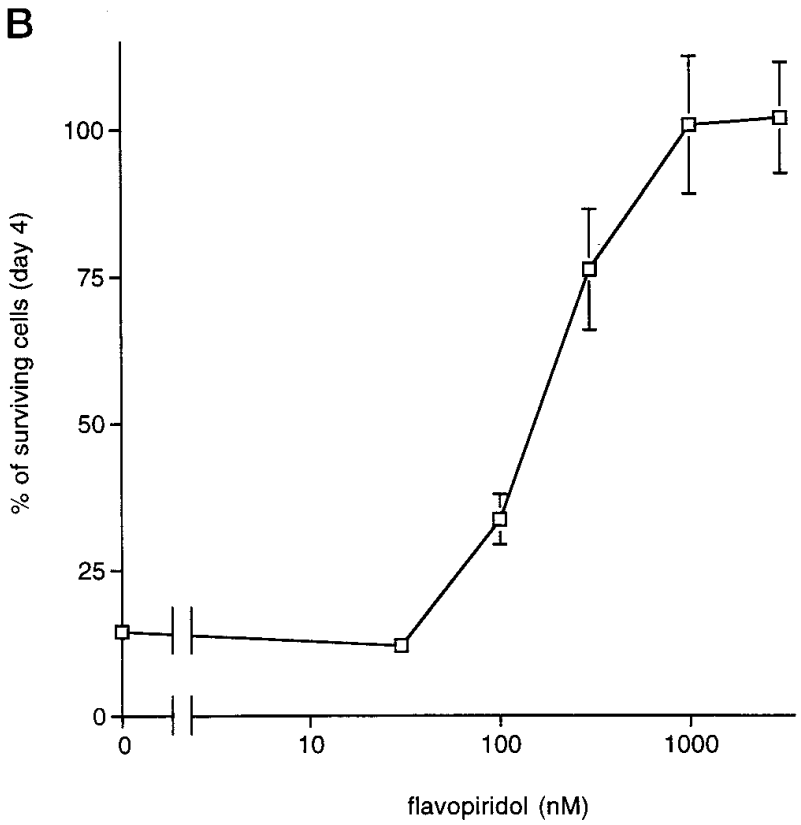

Figure 1. The CDK inhibitors flavopiridol and olomoucine prevent camptothecin-induced death of neuronally differentiated PC12 cells. The neuronal PC12 cell phenotype was attained by treatment with NGF in serum-free medium for $8 \mathrm{~d}$. Replicate cultures were treated with camptothecin $(10 \mu \mathrm{M})$ as indicated. $A$, Effect of flavopiridol $(1 \mu \mathrm{M})$, olomoucine $(200 \mu \mathrm{M})$, and iso-olomoucine $(200 \mu \mathrm{M})$ on the time course of survival of neuronally differentiated PC12 cells after treatment with camptothecin. $B, C$, Effect of various concentrations of flavopiridol and olomoucine on survival of camptothecin-treated neuronally differentiated PC12 cells. Each data point is the mean \pm $\operatorname{SEM}(n=3)$ and is expressed relative to the number of cells initially plated.

the typical phase-bright morphology of viable cells. As reported previously (Park et al., 1996a), the CDK inhibitors appear to partially suppress neurite generation.

Next we examined several additional cell cycle blockers for their ability to inhibit camptothecin-induced death of neuronal PC12 cells. The G1/S blockers mimosine and deferoxamine, as well as the membrane-permeant cAMP analog CPT-cAMP inhibit trophic factor deprivation-induced neuronal apoptosis at concentrations that fully block DNA synthesis in naive PC12 cells (Farinelli and Greene, 1996). At these concentrations, deferoxamine (Fig. $4 A$ ) and mimosine (Fig. $4 B$ ) effectively suppressed death for up to $4 \mathrm{~d}$ of camptothecin treatment. After this time, cell death occurred even in the absence of camptothecin. In addition, CPTcAMP delayed camptothecin-induced death of neuronally differentiated PC12 cells (Fig. $4 C$ ) but was less effective in maintaining 

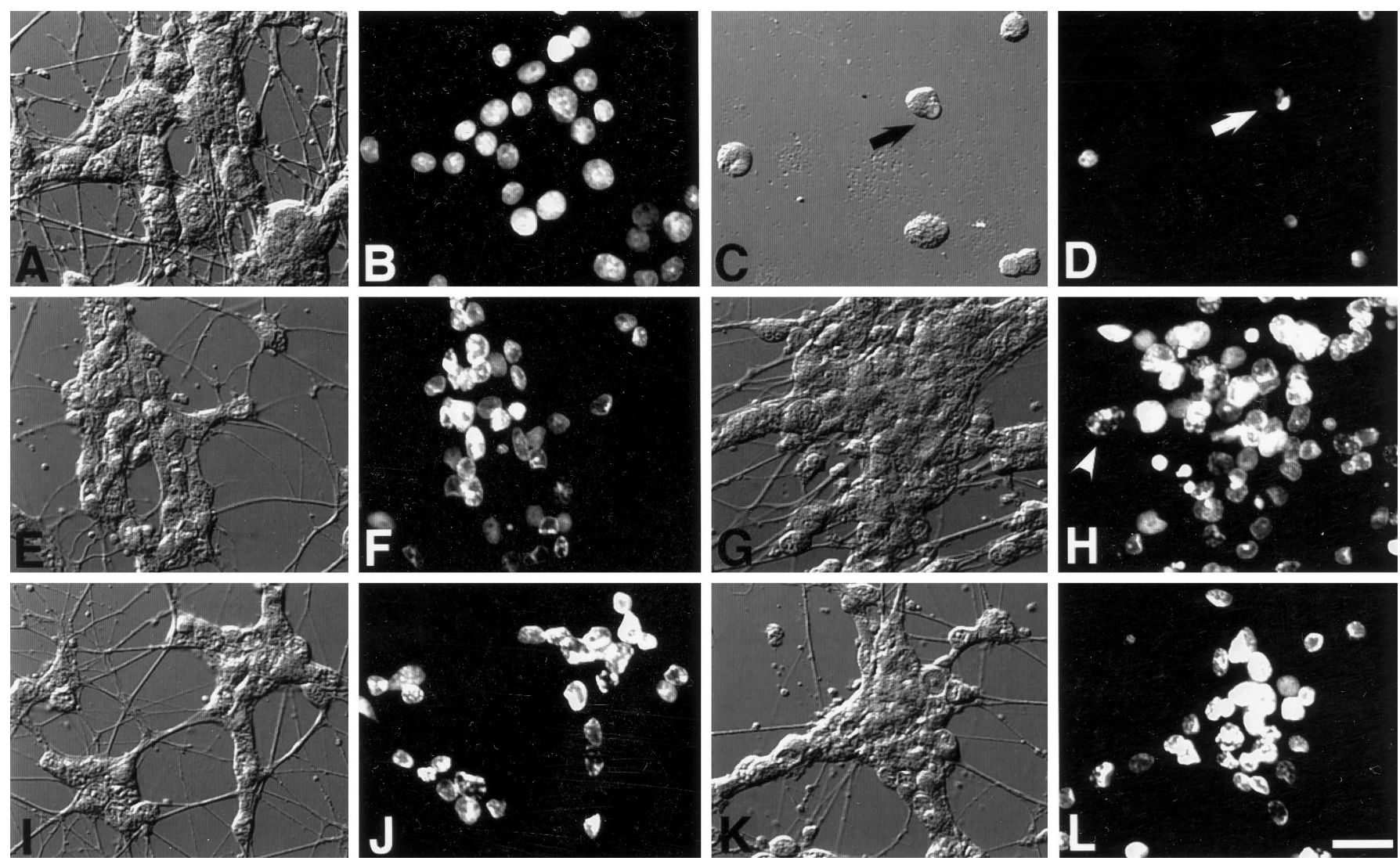

Figure 2. Induction of apoptotic chromatin condensation in neuronal PC12 cells by camptothecin. PC12 cells were neuronally differentiated by treatment with serum-free RPMI 1640 medium containing NGF $(100 \mathrm{ng} / \mathrm{ml})$ for $10 \mathrm{~d}$. Cells were then cultured with serum-free RPMI medium containing NGF in the presence or absence of $10 \mu \mathrm{M}$ camptothecin for $72 \mathrm{hr}$, with or without flavopiridol $(0.5 \mu \mathrm{M})$ or olomoucine $(200 \mu \mathrm{M})$, then fixed and stained with DAPI to visualize nuclear chromatin. Images were captured under differential interference contrast $(A, C, E, G, I, K)$ or fluorescence $(B, D, F, H, J, L)$ optics. Condition depicted are no additives $(A, B)$, camptothecin alone $(C, D)$, camptothecin and flavopiridol $(E, F)$, camptothecin and olomoucine $(G, H)$, flavopiridol alone $(I, J)$, and olomoucine alone $(K, L)$. Camptothecin produced a significant degree of cell death, characterized by blebbing $(C$, arrow $)$ and apoptotic chromatin condensation $(D$, arrow), which could be inhibited by both flavopiridol $(E, F)$ and olomoucine $(G, H)$. However, both flavopiridol and olomoucine, in combination with camptothecin or alone, were able to induce partial changes in chromatin structure $(H$, arrowhead). Scale bar (shown in $L), 20 \mu \mathrm{m}$.

survival than either deferoxamine or mimosine. These data demonstrate that camptothecin-induced apoptosis of neuronal PC12 cells is similar to NGF deprivation-induced apoptosis, in that both can be inhibited by cell cycle blockers.

\section{Aphidicolin and $\mathrm{N}$-acetylcysteine fail to prevent camptothecin- induced death of neuronally differentiated PC12 cells}

Previous studies demonstrated that cell cycle inhibitors that block beyond the G1/S interface do not promote survival of PC12 cells and sympathetic neurons deprived of trophic support (Farinelli and Greene, 1996). Consistent with this observation, the S-phase inhibitor aphidicolin, which inhibits the activity of replicative DNA polymerase $\alpha$, failed to block death of neuronally differentiated PC12 cells treated with camptothecin (Fig. 5A). These data are consistent with the previous observation that aphidicolin does not prevent camptothecin-induced apoptosis of cortical neurons (Morris and Geller, 1996). This implies that camptothecininduced cell death is not dependent on DNA replication and that blockade of DNA synthesis per se is not sufficient to account for the protective actions of G1/S blockers and CDK inhibitors. NAC also inhibits DNA synthesis and protects both neuronal and naive PC12 cells from loss of trophic support (Ferrari et al., 1995; Yan et al., 1995). Similarly to aphidicolin, NAC failed to suppress the death of camptothecin-treated neuronal PC12 cells (Fig. 5B). This supports the notion that inhibition of DNA synthesis alone is inadequate to protect cells from camptothecin. Furthermore, these data indicate that NAC distinguishes between the mechanisms by which trophic factor deprivation and camptothecin induce neuronal apoptosis.

\section{Effects of cell cycle blockers on camptothecin-induced death of naive proliferating PC12 cells}

Camptothecin also induced the death of naive, proliferating PC12 cells, and this was accompanied by chromatin condensation characteristic of apoptosis (data not shown). Camptothecin $(10 \mu \mathrm{M})$ induced maximal death at day 2 after treatment (data not shown). The various cell cycle inhibitors were tested for their ability to block death in this paradigm. Deferoxamine (Fig. 6A), mimosine (Fig. 6B), and CPT-cAMP (Fig. 6C) significantly delayed death caused by camptothecin $(\sim 70-80 \%$ survival after cotreatment with the cell cycle inhibitors vs $25-30 \%$ survival with camptothecin alone on day 2). These agents also promote survival of serumdeprived naive PC12 cells (Rukenstein et al., 1991; Farinelli and Greene, 1996). In the latter case, pretreatment of cells with mimosine and deferoxamine was necessary to promote optimal survival, whereas no pretreatment was necessary for protection against camptothecin-induced death. This difference is most likely attributable to the slower onset of death with camptothecin, which 

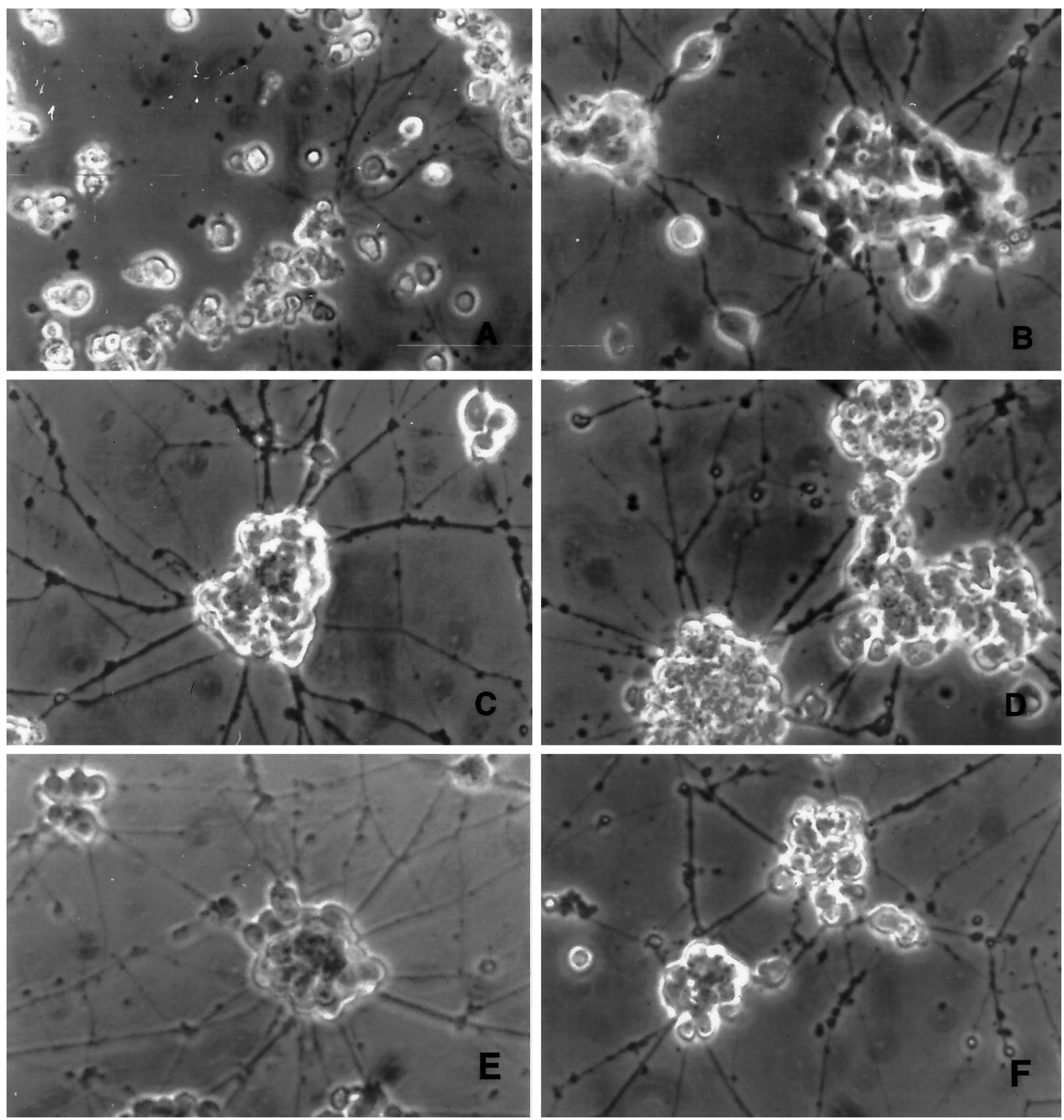

Figure 3. Phase-contrast micrographs of neuronally differentiated PC12 cells maintained in serum-free medium containing NGF and treated for $4 \mathrm{~d}$ with the following: $10 \mu \mathrm{M}$ camptothecin $(A)$; no additives $(B) ; 10 \mu \mathrm{M}$ camptothecin $+1 \mu \mathrm{M}$ flavopiridol $(C) ; 10 \mu \mathrm{M}$ camptothecin $+200 \mu \mathrm{M}$ olomoucine $(D)$; $1 \mu \mathrm{M}$ flavopiridol $(E) ; 200 \mu \mathrm{M}$ olomoucine $(F)$.

permits sufficient uptake of the drug before an irreversible commitment to apoptosis (Farinelli and Greene, 1996) (Fig. 6).

Previous reports suggest that the mechanism of camptothecininduced apoptosis in proliferating cells is attributable to the formation of DNA double-strand breaks formed during collision of the replication machinery and the camptothecin/topo-I/DNA ternary complex (called the cleavable complex) (Hsiang et al., 1985). Consistent with this, aphidicolin has been shown to prevent camptothecin-induced death of cycling cells (Hsiang et al., 1989; D'Arpa et al., 1990). However, our observations fail to support this model for naive, cycling PC12 cells. Both aphidicolin (Fig. $6 D$ ) and NAC (data not shown) failed to suppress camptothecin cytotoxicity at concentrations that inhibit DNA synthesis (Ferrari et al., 1995). Thus, as in the case with neuronal PC12 cells, inhibition of DNA synthesis alone is not the deciding factor that determines whether a particular agent protects cells from camptothecin-induced apoptosis.

\section{The CDK inhibitors flavopiridol and olomoucine inhibit death of camptothecin-treated sympathetic neurons}

Next we investigated whether agents effective on PC12 cells also protect cultured rat sympathetic neurons from camptothecininduced death. Typically, after $3 \mathrm{~d}$ of camptothecin exposure (10 $\mu \mathrm{M}), \sim 50 \%$ of these neurons died and most were dead after $5 \mathrm{~d}$ 
A
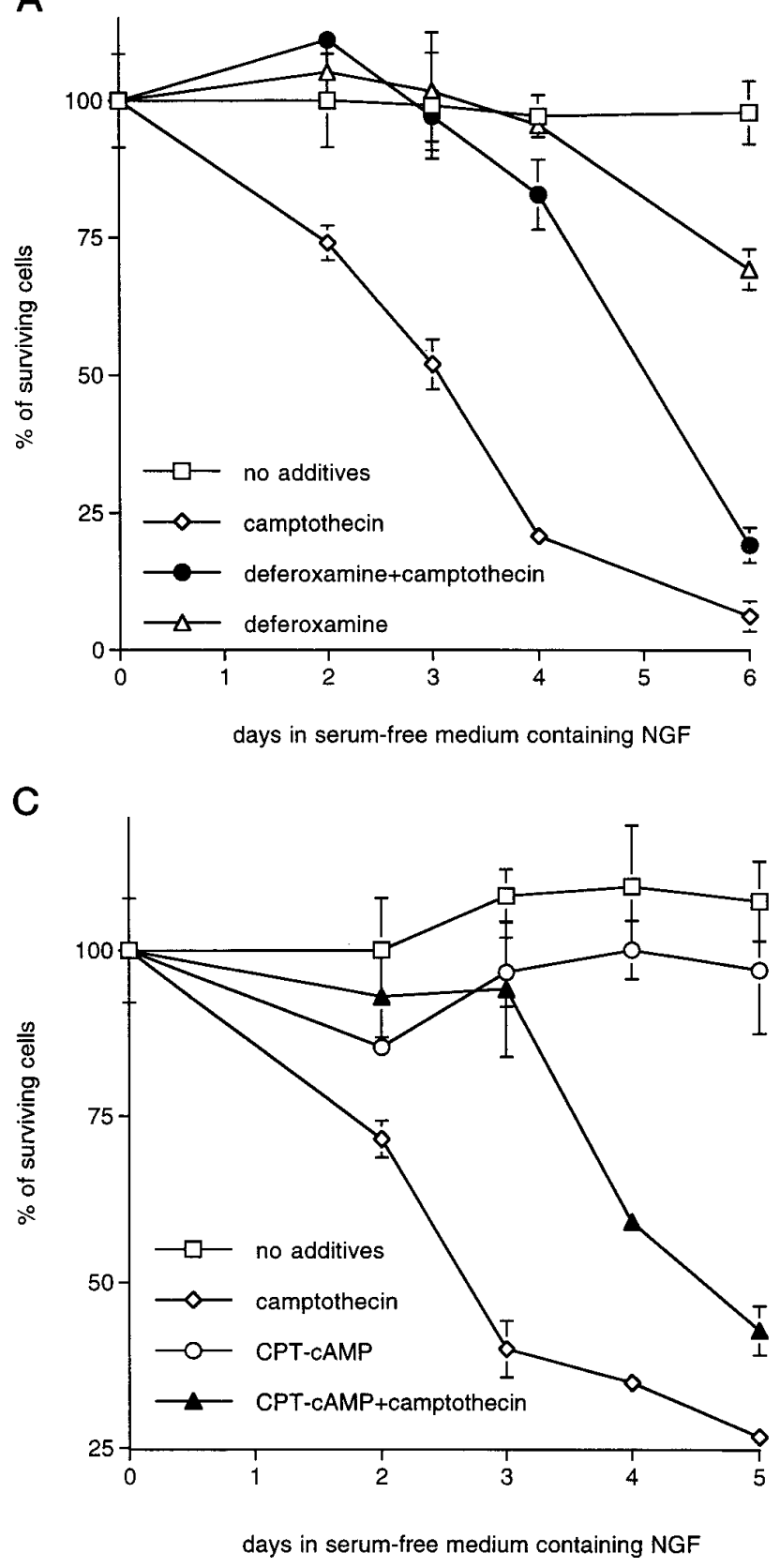

of treatment (Fig. 7A). This death was not attributable to general inhibition of transcription, because exposure to actinomycin D treatment $(10 \mu \mathrm{M})$, which also blocks transcription, did not result in death until day 6 (Fig. 7A). As observed with camptothecintreated cortical neurons (Morris and Geller, 1996), as well as trophic factor deprived sympathetic neurons and neuronal PC12 cells (Martin et al., 1988; Mesner et al., 1992), actinomycin D treatment prevented the death of camptothecin-treated sympathetic neurons (data not shown).

Flavopiridol (Fig. 7 $A, B$ ) and olomoucine (Fig. 7C,D) protected sympathetic neurons from camptothecin-induced death at concentrations of $1 \mu \mathrm{M}$ and $200 \mu \mathrm{M}$, respectively. At these levels, full protection occurred for a period of $5 \mathrm{~d}$ of continuous incubation. Treatment of neurons with either agent alone in the absence of camptothecin resulted in $\sim 30 \%$ cell death at day 6 (data not shown), as did exposure to actinomycin D alone

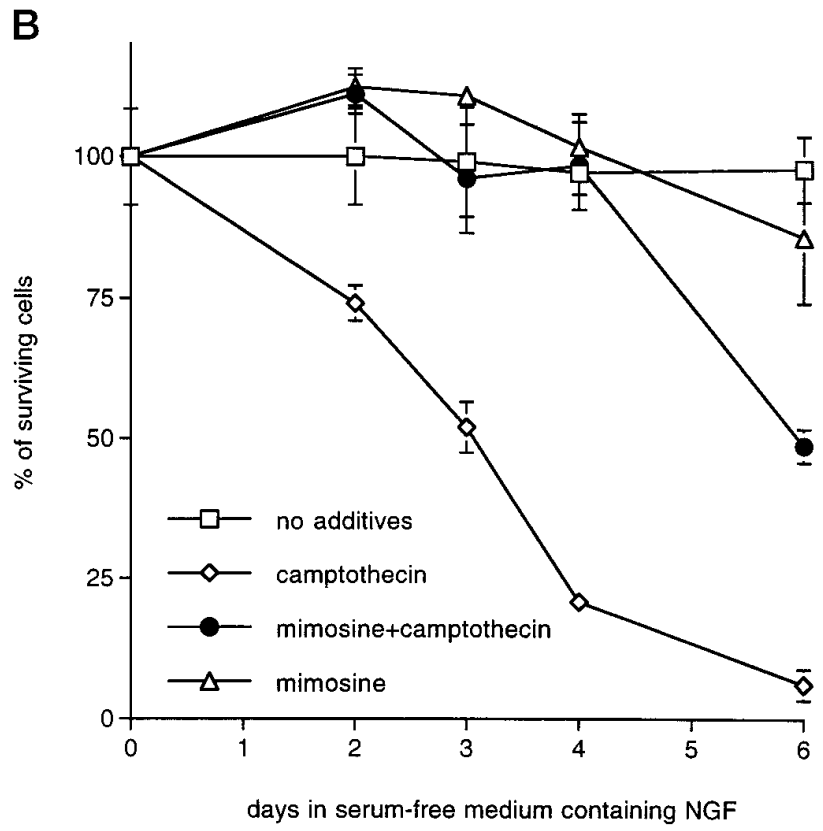

Figure 4. CPT-cAMP and the G1/S blockers deferoxamine and mimosine suppress camptothecin-induced death of neuronally differentiated PC12 cells. Replicate cultures were treated with camptothecin $(10 \mu \mathrm{M})$ as indicated. Effect of deferoxamine $(1 \mathrm{mM})(A)$, mimosine $(400 \mu \mathrm{M})(B)$, and CPT-cAMP $(100 \mu \mathrm{M})(C)$ on the time course of survival of neuronally differentiated PC12 cells after treatment with camptothecin. Each data point is the mean $\pm \operatorname{SEM}(n=$ 3 ) and is expressed relative to the number of cells initially plated.

(Fig. 7A). Flavopiridol and olomoucine inhibited camptothecin-induced death with $\mathrm{IC}_{50}$ values of $100 \mathrm{~nm}$ and 50 $\mu \mathrm{M}$, respectively; these concentrations are similar to those reported for inhibition of NGF deprivation-induced death (Park et al., 1996a). In addition, as with PC12 cells, isoolomoucine was not effective in promoting survival (Fig. $7 C$ ). NAC also failed to promote survival of camptothecin-treated sympathetic neurons (data not shown), again consistent with our PC12 cell results. Figure 8 illustrates the morphology of camptothecin-treated sympathetic neurons cultured in the presence or absence of flavopiridol and olomoucine. Phasebright cell bodies and healthy processes were maintained in the flavopiridol- or olomoucine-treated cultures $5 \mathrm{~d}$ after the start of camptothecin treatment. In contrast, cultures treated with camptothecin alone showed degenerating neurites and cell bodies. 
A

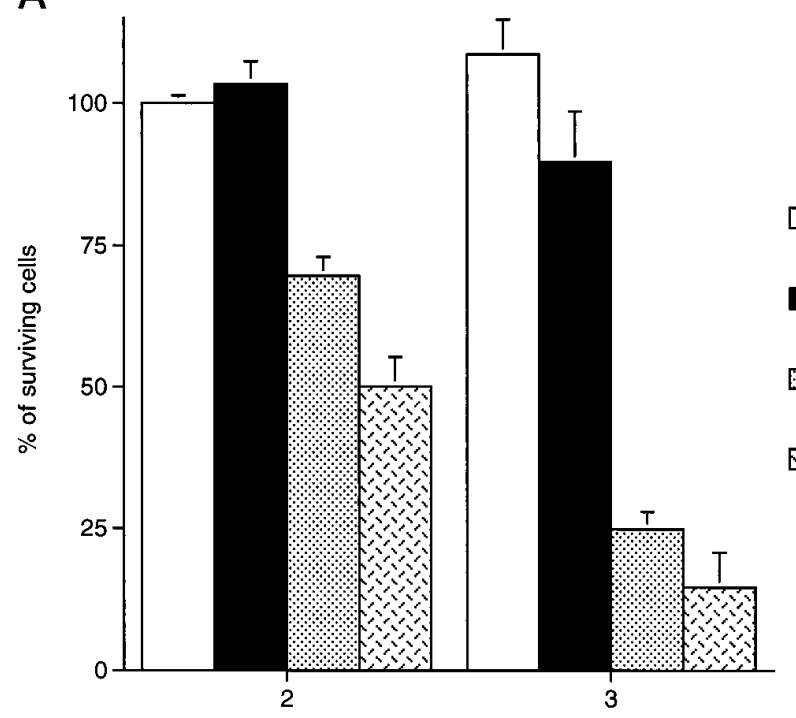

days in serum-free medium containing NGF
B

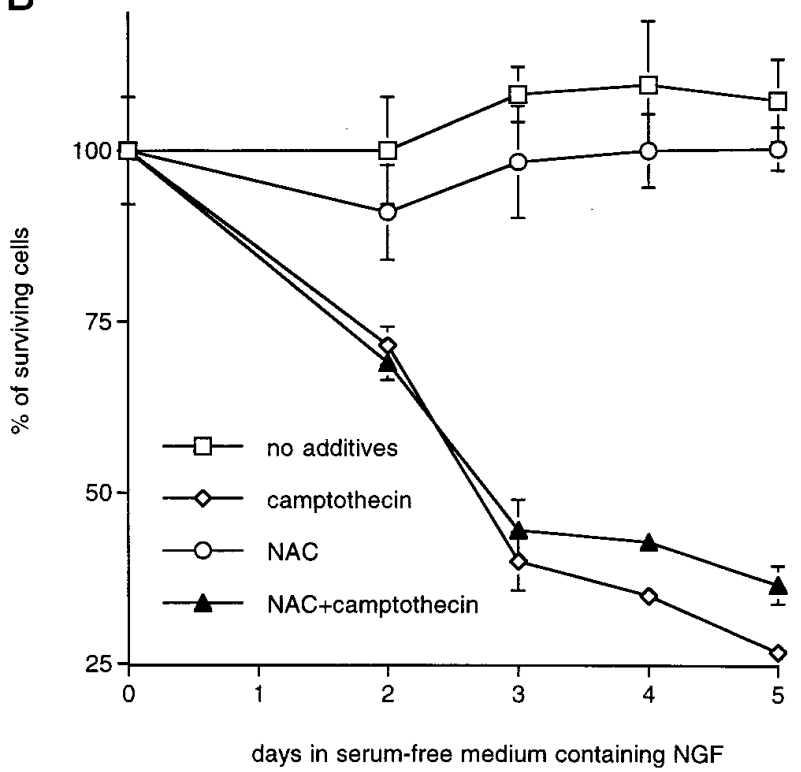

Figure 5. Aphidicolin $(A)$ and NAC $(B)$ do not block camptothecin-mediated death of neuronally differentiated PC12 cells. Replicate cultures were treated with and without $10 \mu \mathrm{M}$ camptothecin in the presence and absence of aphidicolin $(10 \mu \mathrm{M})$ or NAC $(60 \mathrm{mM})$ as indicated. Each data point is the mean $\pm \operatorname{SEM}(n=3)$ and is expressed relative to the number of cells initially plated.

\section{The ICE family protease inhibitor zVAD-fmk protects sympathetic neurons from NGF deprivation but not camptothecin cytotoxicity}

NGF-deprived sympathetic neurons can be rescued from death by the cysteine aspartase inhibitor zVAD-fmk (Park et al., 1996b; Troy et al., 1996). At $100 \mu \mathrm{M}$, zVAD-fmk fully protects the neurons after $3 \mathrm{~d}$ of NGF deprivation (Fig. 9A). At this time, $\sim 90 \%$ of the neurons in untreated, NGF-deprived cultures are dead. In contrast, the same concentration of zVAD-fmk has no effect on the kinetics of death in camptothecin-treated cultures (Fig. 9B). These observations suggest that there is a divergence in apoptotic signaling events triggered by trophic factor withdrawal and exposure to camptothecin, in that camptothecin-induced apoptosis of neurons is not inhibited by the cysteine aspartase inhibitor zVAD-fmk.

\section{Effects of the cell cycle blockers on camptothecin- induced death of cerebral cortical neurons}

Previous studies have demonstrated that camptothecin causes apoptotic death of neurons cultured from the embryonic rat cerebral cortex (Morris and Geller, 1996). To determine whether camptothecin-induced cortical neuronal death could be inhibited by CDK inhibitors, initial experiments were carried out by treating mixed cultures with $10 \mu \mathrm{M}$ camptothecin in the presence or absence of $0.5 \mu \mathrm{M}$ flavopiridol or $200 \mu \mathrm{M}$ olomoucine and evaluating neuronal survival at $24 \mathrm{hr}$. The cells were also fixed and DAPI-stained to visualize nuclear chromatin morphology. Control cultures consisted of healthy, phase-bright, process-bearing neurons on top of a confluent monolayer of astrocytes (Fig. 10A), with the neuronal nuclei appearing bright, round, and intact (Fig. $10 B$ ). Camptothecin treatment resulted in neuronal death without any obvious effects on the astrocyte monolayer (Fig. 10C). In addition, the morphology of the neurons treated with camptothecin was characterized by somal blebbing and neurite degeneration (Fig. 10C) as well as nuclear chromatin condensation typical of apoptosis (Fig. 10D). Cotreatment with camptothecin and flavopiridol (Fig. 10E,F) or olomoucine (Fig. 10G,H) completely prevented camptothecin-induced death, and the neurons appeared as healthy as neurons in control cultures. In addition, both CDK inhibitors prevented camptothecin-induced apoptotic chromatin condensation (Fig. $10 F, H$ ).

To quantify the degree of protection afforded by the CDK inhibitors, mixed cultures were treated with $10 \mu \mathrm{M}$ camptothecin in the presence and absence of increasing concentrations of flavopiridol, olomoucine, and iso-olomoucine. Camptothecin treatment alone resulted in $\sim 70 \%$ neuronal death by $24 \mathrm{hr}$ (as determined by the CFDA assay). Both flavopiridol (Fig. 11 $A$ ) and olomoucine (Fig. 11B) significantly prevented camptothecininduced neuronal death in a dose-dependent manner, with $\mathrm{IC}_{50}$ values of $\sim 0.1 \mu \mathrm{M}$ and $100 \mu \mathrm{M}$, respectively. In contrast, cotreatment with up to $200 \mu \mathrm{M}$ iso-olomoucine failed to prevent camptothecin-induced neuronal death (Fig. 11C). These data further suggest that camptothecin-induced apoptosis of CNS neurons involves inappropriate cell cycle signals that can be inhibited by cell cycle inhibitors. In support of this hypothesis, both deferoxamine and mimosine were also able to delay camptothecininduced apoptosis of cortical neurons (data not shown). However, both of these agents were significantly toxic to cortical neurons by themselves.

\section{DISCUSSION}

The data presented here demonstrate that camptothecin-induced apoptotic cell death can be inhibited by several agents that interact with cell cycle regulatory mechanisms. These include inhibitors of CDKs as well as agents that block the G1/S transition in dividing cells. This suggests that the signals that trigger cell death in response to camptothecin involve cell cycle signals that precede entry into the S-phase. This would be consistent with the presence of a critical checkpoint before the G1/S border that, once passed, results in neuronal death. In proliferating cells, this point appears to coincide with the G1/S restriction point, after which cell cycle 
A

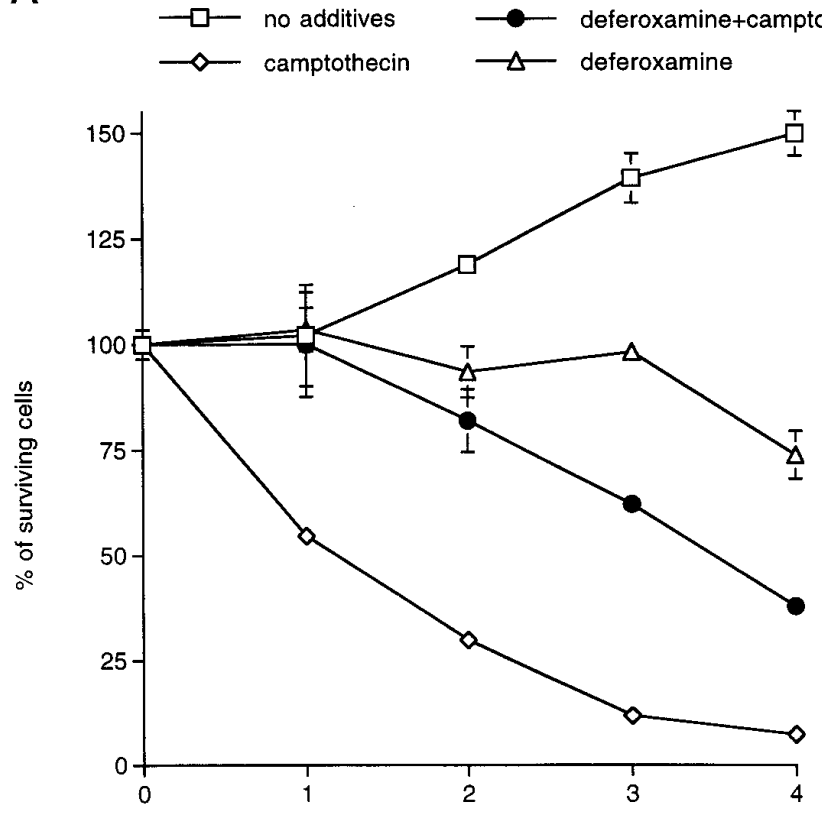

days in serum-containing medium

\section{C}

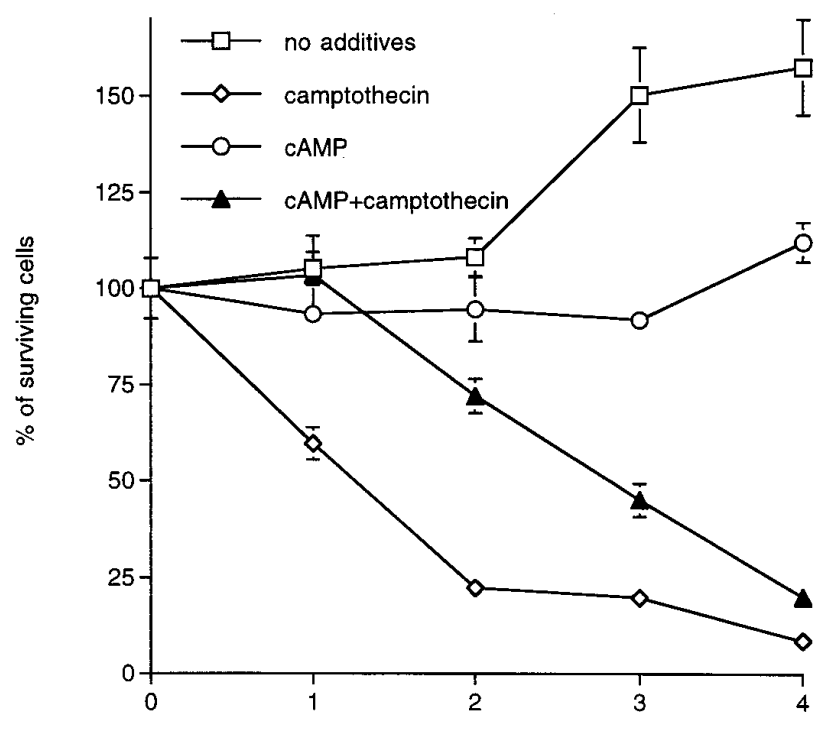

days in serum-containing medium
B
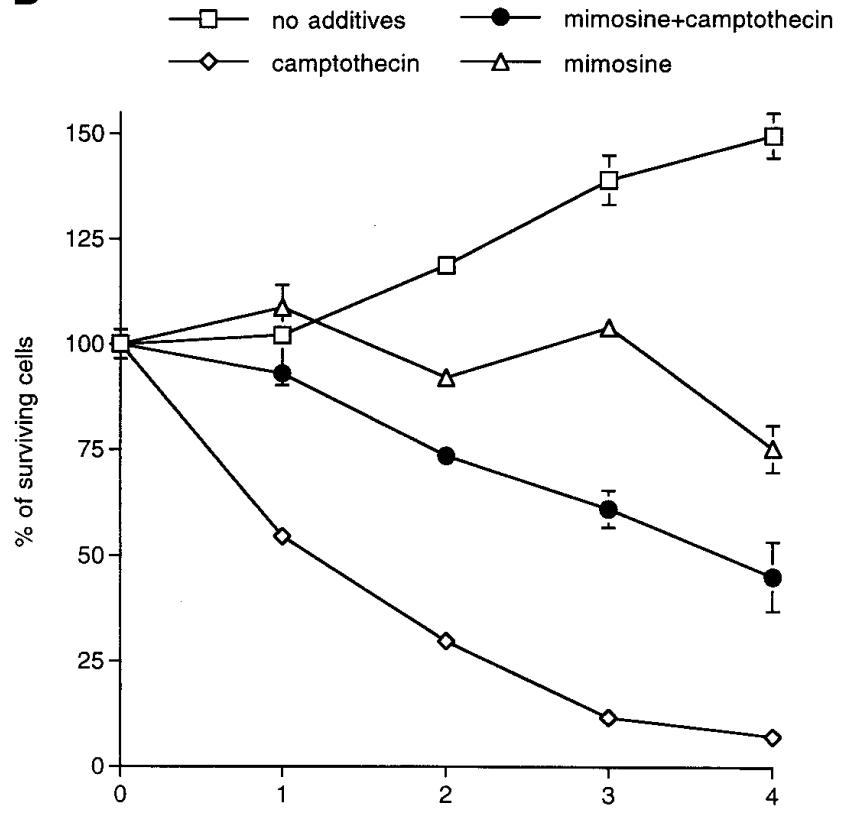

days in serum-containing medium

D
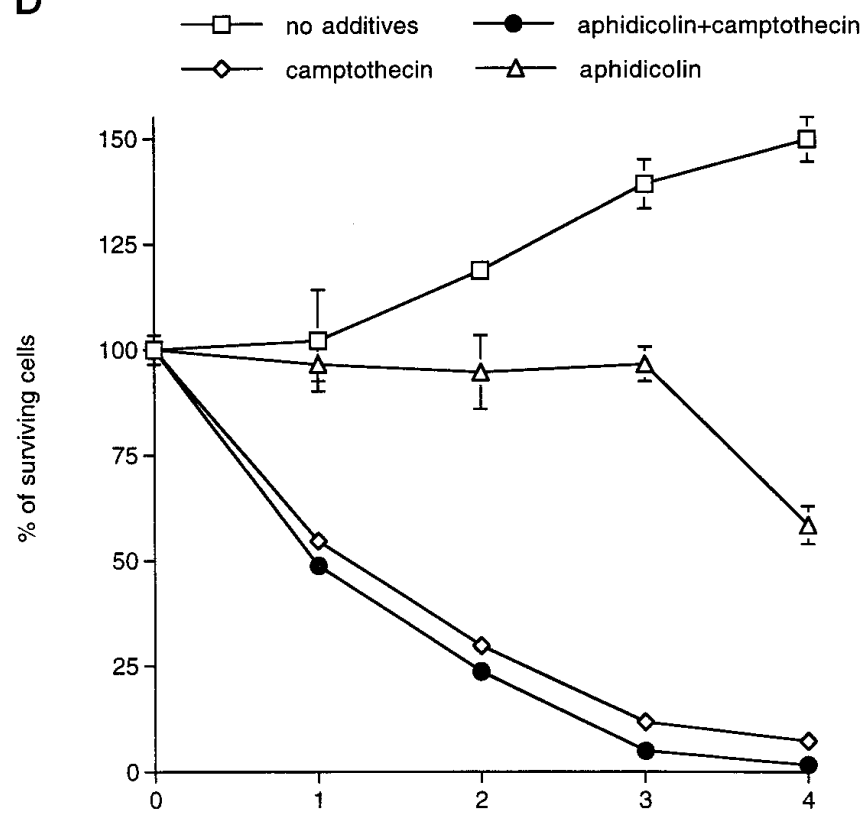

days in serum-containing medium

Figure 6. Effect of cell cycle blockers on camptothecin-induced death of naive PC12 cells. Cells were cultured in the presence of serum with and without $10 \mu \mathrm{M}$ camptothecin as indicated. Replicate naive PC12 cell cultures were grown as indicated in the presence of $1 \mathrm{~mm}$ deferoxamine $(A)$; $400 \mu \mathrm{M}$ mimosine $(B) ; 100 \mu \mathrm{M}$ CPT-cAMP $(C)$; or $10 \mu \mathrm{M}$ aphidicolin $(D)$. Each data point is the mean $\pm \operatorname{SEM}(n=3)$ and is expressed relative to the number of cells initially plated.

control cannot be maintained and the cell is committed to continue through the cell cycle (Pardee et al., 1974). It may be that this checkpoint is important in controlling apoptosis in nondividing cells as well.

Cell cycle checkpoints are primarily controlled by the activity of CDKs and their interactions with their cognate cyclins (Morgan, 1995). Changes in the activity of CDKs and cyclins are also observed during apoptosis of many different cell types. For instance, death of HL60 cells caused by camptothecin and araC is associated with elevated cdc2 activity (Shimizu et al., 1995) and cyclin E-associated kinase activity (Ping Dou et al., 1995), respectively. Also, camptothecin-induced apoptosis of RKO cells is associated with an increase in expression of cyclin D1 (Chen et al., 1995). In addition, other pharmacological agents that induce 
A

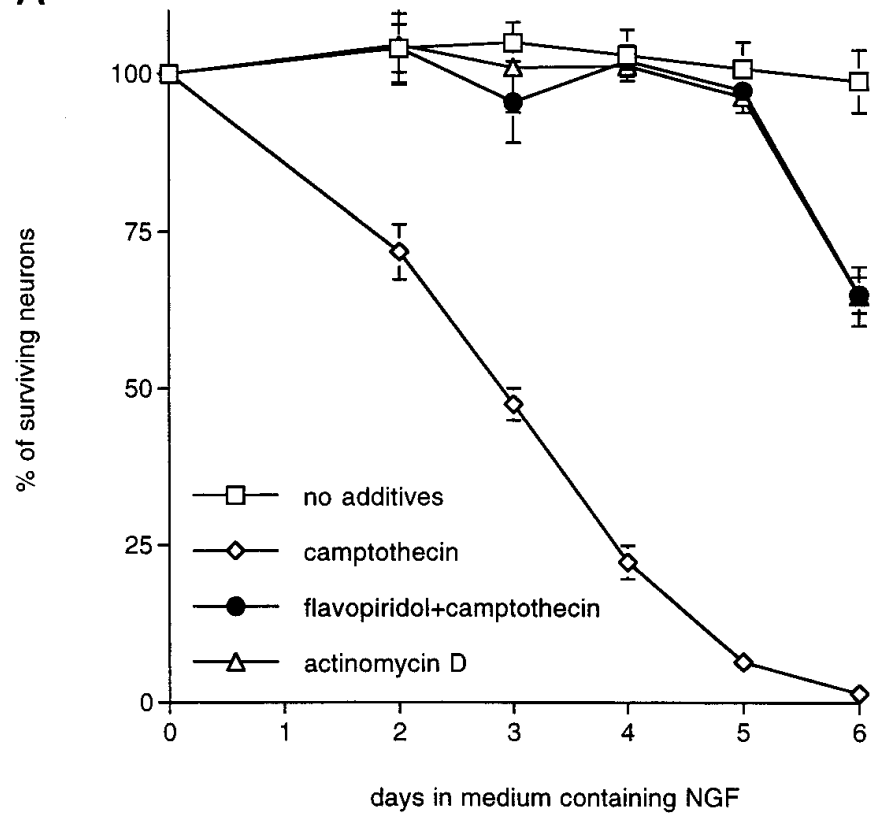

C

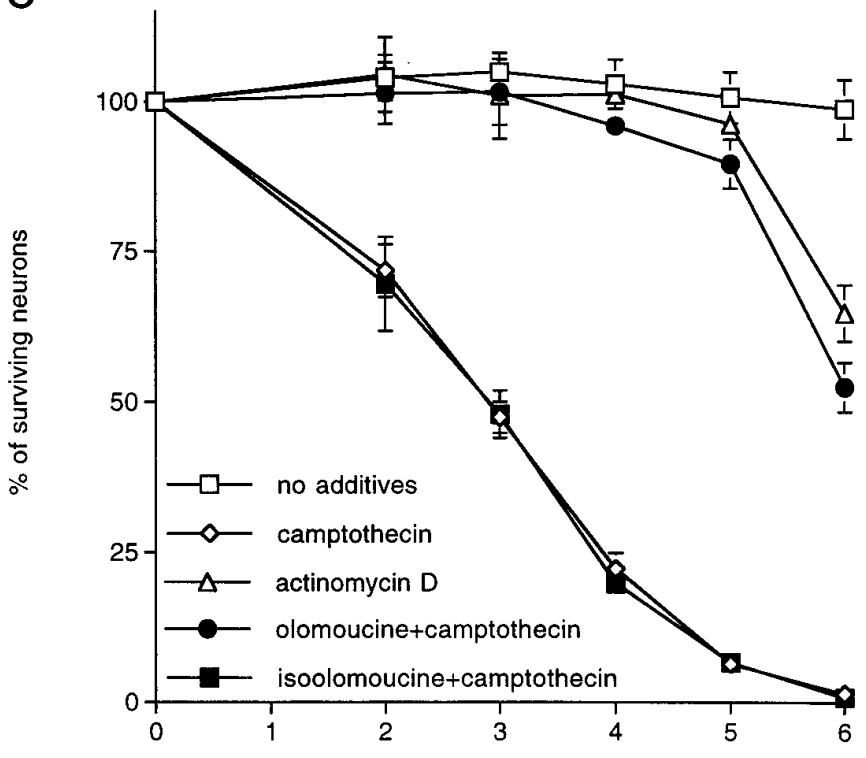

days in medium containing NGF
B

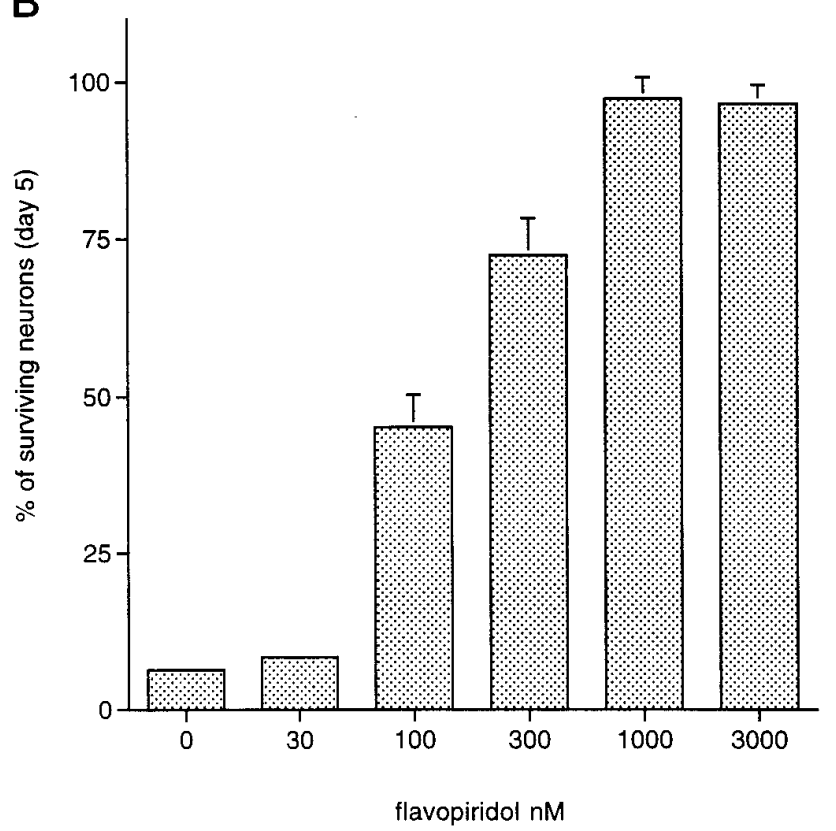

D

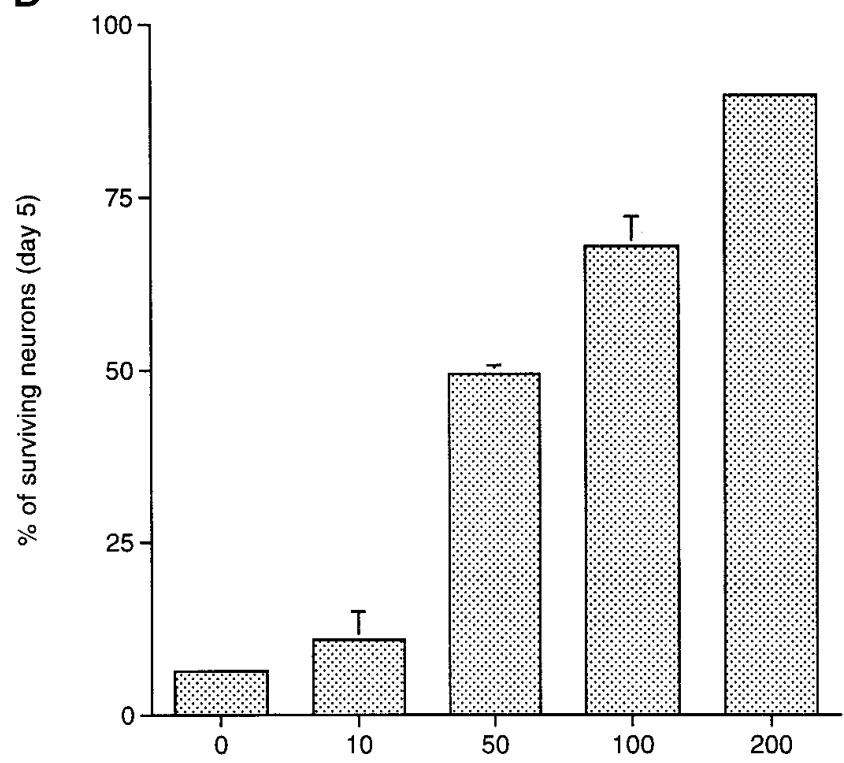

olomoucine $\mu \mathrm{M}$

Figure 7. The CDK inhibitors flavopiridol and olomoucine inhibit the camptothecin-induced death of rat sympathetic neurons. Primary cultures of neonatal rat superior cervical ganglion neurons were grown in the presence of NGF for $3 \mathrm{~d}$ before drug treatment. Replicate cultures were treated with camptothecin $(10 \mu \mathrm{M})$ as indicated. Each data point is the mean $\pm \operatorname{SEM}(n=3)$ and is expressed relative to the number of neurons present in each culture at the time of drug treatment. $A$, Effects of flavopiridol $(1 \mu \mathrm{M})$ on the time course of survival of sympathetic neurons treated with camptothecin. Actinomycin D $(10 \mu \mathrm{M})$ treatment is included to control for death induced by inhibition of transcription. $B$, Effects of various doses of flavopiridol on the survival of camptothecin-treated sympathetic neurons at $5 \mathrm{~d}$ in vitro. $C$, Effects of olomoucine and iso-olomoucine (200 $\mu \mathrm{M})$ on the time course of survival of sympathetic neurons treated with camptothecin. Actinomycin D $(10 \mu \mathrm{M})$ treatment is included to control for death induced by inhibition of transcription. $D$, Effects of various doses of olomoucine on the survival of camptothecin-treated sympathetic neurons at $5 \mathrm{~d}$ in vitro.

apoptosis also upregulate cyclin A-associated CDK activity (Hoang et al., 1994; Meikrantz et al., 1994), and expression of dominant-negative mutants of $\operatorname{cdc} 2, \operatorname{cdk} 2$, and $\operatorname{cdk} 3$ suppress apoptosis in HeLa cells (Meikrantz and Schlegel, 1996).

Although these effects have been reported in proliferating cells, several lines of evidence also implicate cyclins and CDKs in neuronal death. NGF deprivation leads to increased cdc2 activity and cyclin B expression in neuronal PC12 cells (Brooks et al., 1993; Gao and Zelenka, 1995), as well as elevated cyclin D1 transcript levels in sympathetic neurons (Freeman et al., 1994). Furthermore, expression of the CDK inhibitor $\mathrm{p} 21$ is required for survival of differentiated neuroblastoma cells (Poluha et al., 1996), 

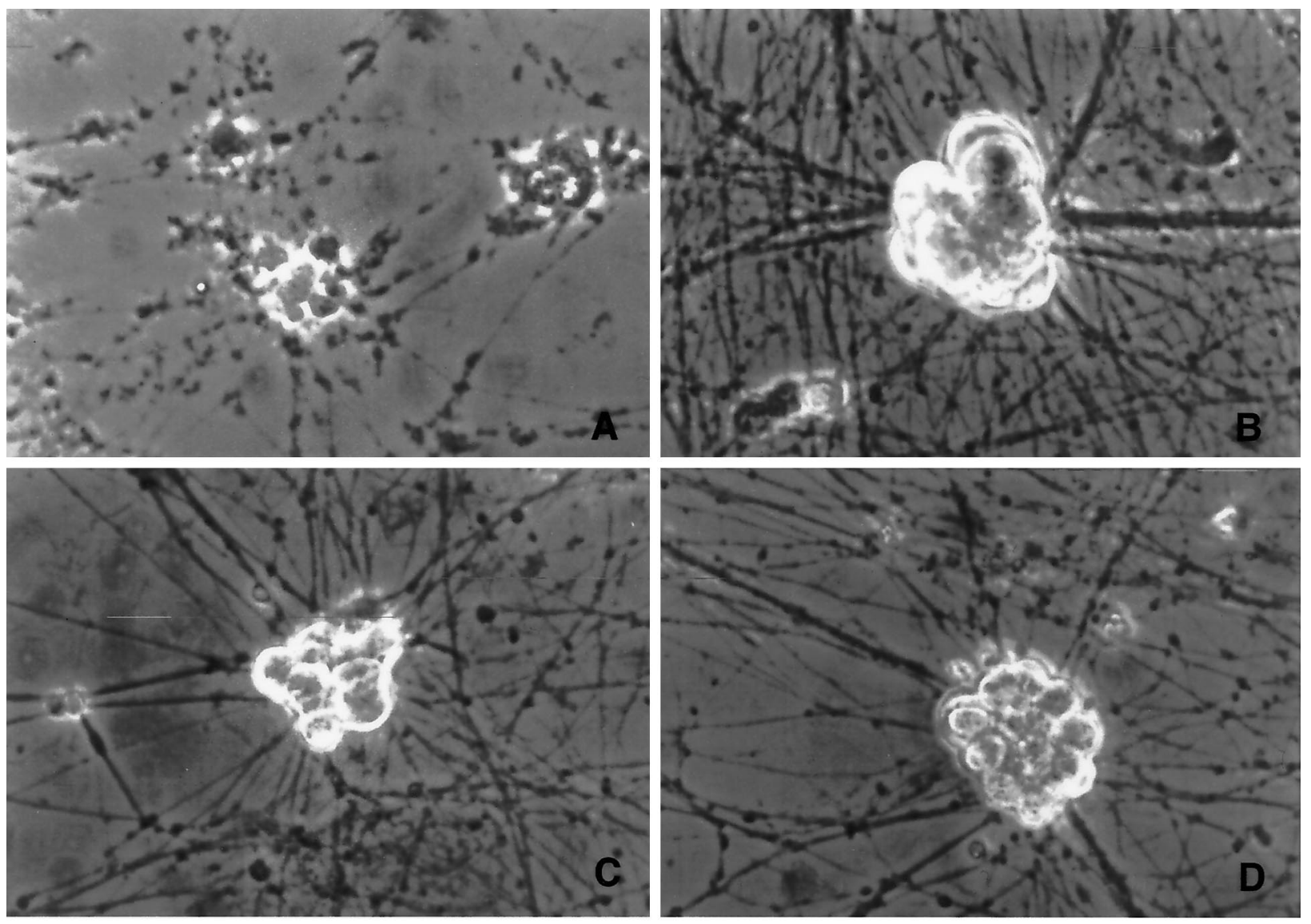

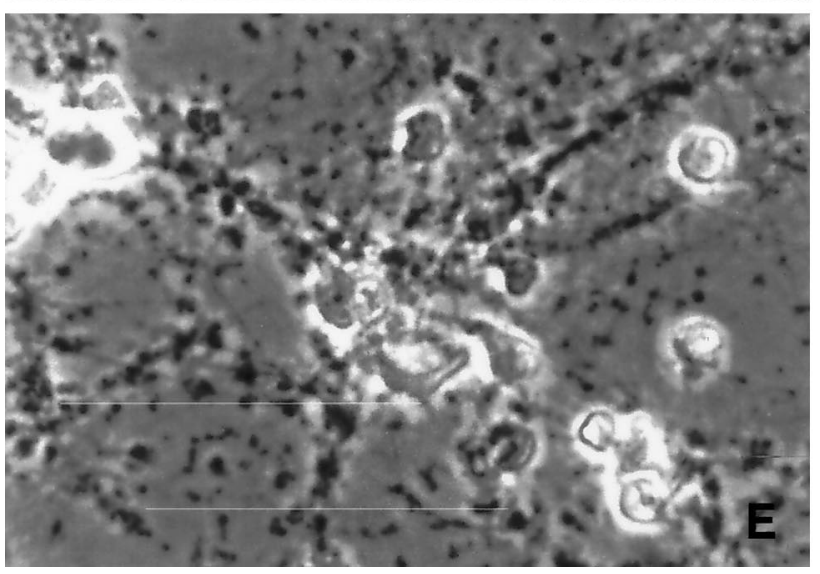

and the CDK inhibitor p16 protects these cells from death caused by trophic factor deprivation (Kranenburg et al., 1996). Finally, the CDK inhibitors olomoucine and flavopiridol block death of sympathetic neurons and neuronal PC12 cells deprived of trophic support (Park et al., 1996a). These data therefore suggest that after loss of a trophic signal, a cell cycle-related pathway involving the cyclin-CDK machinery is turned on inappropriately, and this improper signal ultimately serves to activate the apoptotic pathway.

In light of such findings, we hypothesized that apoptosis of postmitotic neurons, induced by the DNA-damaging agent camptothecin, may also involve deregulated cell cycle signaling. We tested this model by examining whether known CDK inhibitors as well as other cell cycle blockers promote survival of camptothecintreated neuronal cells. In agreement, both flavopiridol and olo-
Figure 8. Phase-contrast micrographs of primary sympathetic neurons maintained in medium containing NGF and treated for $5 \mathrm{~d}$ with the following: $10 \mu \mathrm{M}$ camptothecin $(A)$; no additives $(B)$; camptothecin $+1 \mu \mathrm{M}$ flavopiridol $(C)$; camptothecin $+200 \mu \mathrm{M}$ olomoucine $(D)$; camptothecin $+200 \mu \mathrm{M}$ iso-olomoucine $(E)$.

moucine blocked the death of neuronally differentiated PC12 cells, sympathetic neurons, and cerebral cortical neurons caused by exposure to camptothecin. Significantly, the doses of inhibitors required to promote neuronal survival correlate closely with the concentrations required to inhibit thymidine incorporation by dividing PC12 cells (Park et al., 1996a). In addition, the G1/S blockers deferoxamine and mimosine also suppressed camptothecin-induced death of neuronal PC12 cells and cortical neurons and did so at concentrations at which they block DNA synthesis. Because the CDK inhibitors (Park et al., 1996a) and G1/S inhibitors (Farinelli and Greene, 1996) have minimal effect on protein synthesis of neuronal PC12 cells and sympathetic neurons, it is unlikely that these agents protect neurons from camptothecin-induced apoptosis by acting as a general protein synthesis inhibitor. 
A

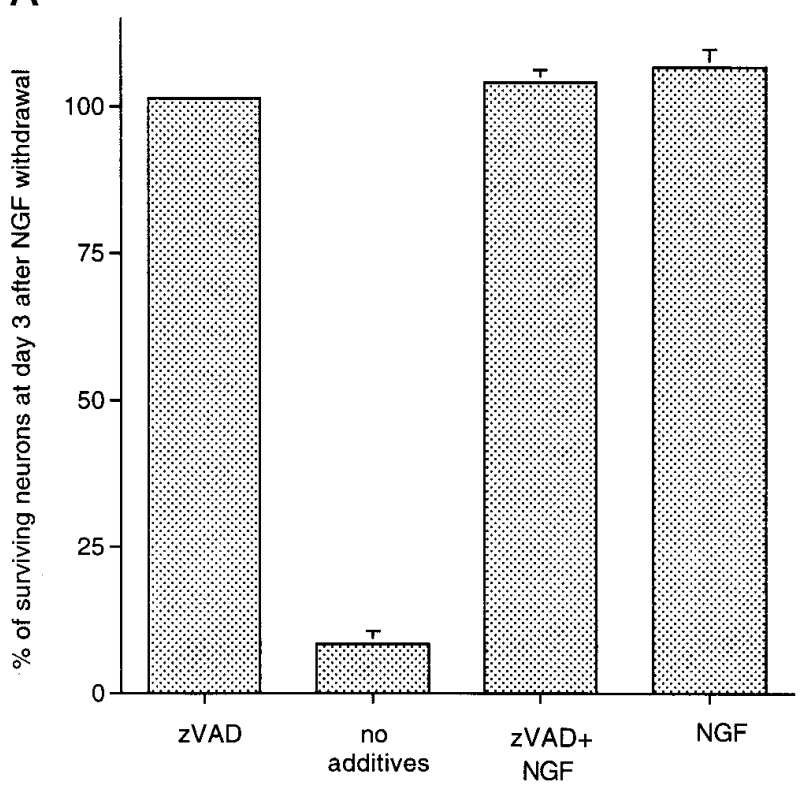

B

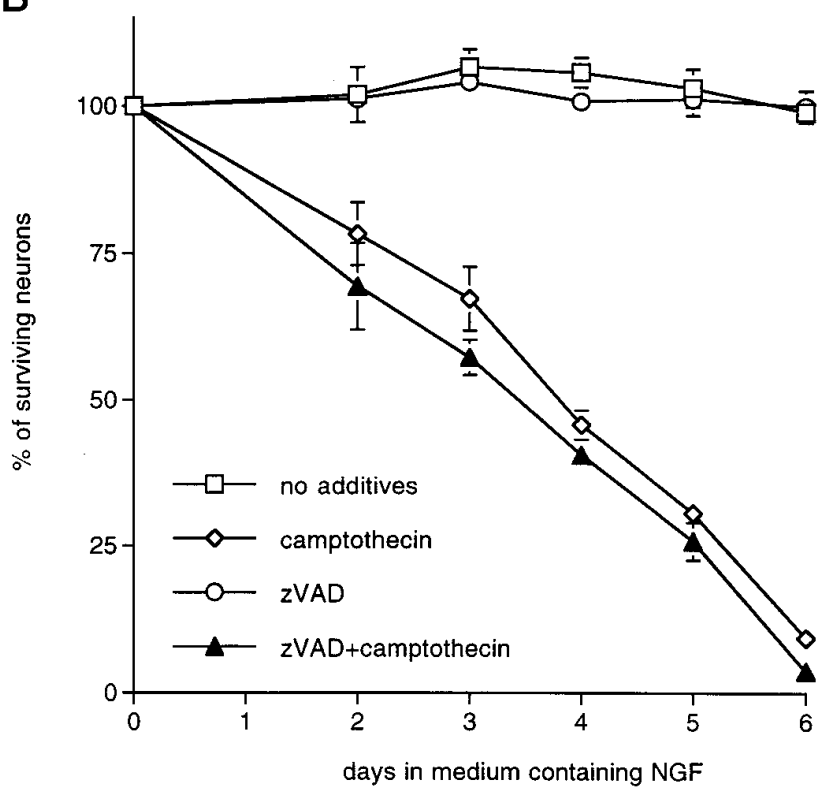

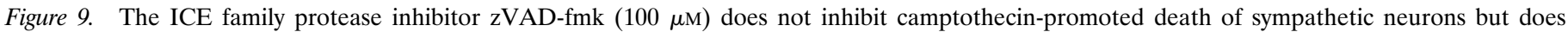

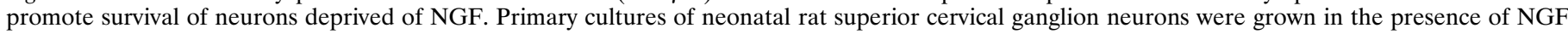

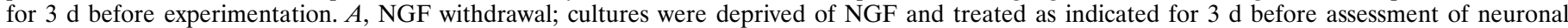

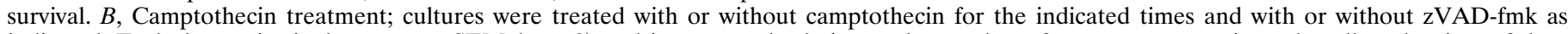

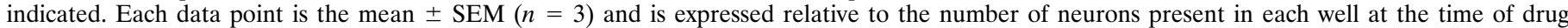
treatment.

Although our findings support involvement of cell cycle components in camptothecin-induced apoptosis, protection is not conferred by inhibition of the cell cycle per se. Whereas CDK inhibitors and G1/S blockers provided effective protection from camptothecin-promoted death, the S-phase blocker aphidicolin did not. This selectivity has also been observed in death induced by trophic factor deprivation (Farinelli and Greene, 1996) and appears to indicate that agents that block at stages in the cell cycle later than the G1/S interface may not be effective in preventing neuronal apoptosis. This is not unexpected, given the fact that postmitotic neurons are quiescent and do not synthesize DNA.

Although our findings are consistent with the notion of inappropriate cell cycle signaling as the cause of camptothecininduced neuronal apoptosis, other explanations must be considered. Deferoxamine (Ganeshaguru et al., 1980) and mimosine (Kontoghiorghes and Evans, 1985) may act as scavangers of reactive oxygen. However, the concentration of deferoxamine required to prevent $\mathrm{PC} 12$ cell death caused by oxidative stress is several orders of magnitude lower than that required to prevent camptothecin-induced death (Troy and Shelanski, 1994). In addition, it is conceivable that flavopiridol and olomoucine inhibit kinases other than CDKs that are important in death. Although previous work has ruled out blockade of the activation or activity of the apoptosis-required c-Jun kinase (Park et al., 1996a), and experiments to date have indicated that flavopiridol in particular appears to be highly selective for CDKs, we cannot rule out actions on kinases that have yet to be evaluated.

Although neuronal death caused by both trophic factor deprivation and camptothecin exposure are suppressed by CDK inhibitors and G1/S blockers, there are also important differences between the two paradigms. First, although NGF inhibits death caused by withdrawal of trophic support, it did not protect PC12 cells and sympathetic neurons from death induced by campto- thecin. Similarly, NAC, which also supports the survival of trophic factor-deprived PC12 cells and sympathetic neurons, does not protect against camptothecin. Thus, this agent may protect trophic factor-deprived neural cells by a mechanism independent of its cell cycle effects, or the manner in which it inhibits DNA synthesis may be incompatible with protection from DNA damage.

Most importantly, whereas the ICE family cysteine aspartase inhibitor zVAD-fmk protects PC12 cells and sympathetic neurons from NGF deprivation (Park et al., 1996b; Troy et al., 1996), it had no effect on apoptosis induced by camptothecin. This suggests that the nature of the deregulated cell cycle signaling is different and/or the pathways by which cells die in the two paradigms must diverge. Because ICE/cysteine aspartase-like enzymes appear to be causally involved in apoptosis induced by a variety of different initiating stimuli, one possibility that explains this divergence is that death induced by camptothecin involves ICE family cysteine aspartase members that are not sensitive to zVAD-fmk. Recent findings demonstrate that different ICE/cysteine aspartase family members mediate PC12 cells death evoked by NGF deprivation and by superoxide dismutase 1 downregulation (Troy et al., 1996).

The mechanism by which camptothecin may potentially induce deregulated cell cycle signaling is unclear. Camptothecin is known to inhibit RNA synthesis (Horwitz et al., 1971), induce c-jun mRNA in myeloid leukemia cells (Kharbanda et al., 1991), and cause differentiation of certain leukemia lines (McSheehy et al., 1991; Aller et al., 1992). It is clear that the ability of camptothecin to inhibit RNA synthesis per se does not contribute to its neuronal cytotoxicity, because actinomycin $\mathrm{D}$ treatment, which also blocks transcription, protects neurons from camptothecin-induced apoptosis. In light of this observation, Morris and Geller (1996) have recently proposed that camptothecin causes transcriptional machinery-driven formation of DNA strand breaks in neurons. 

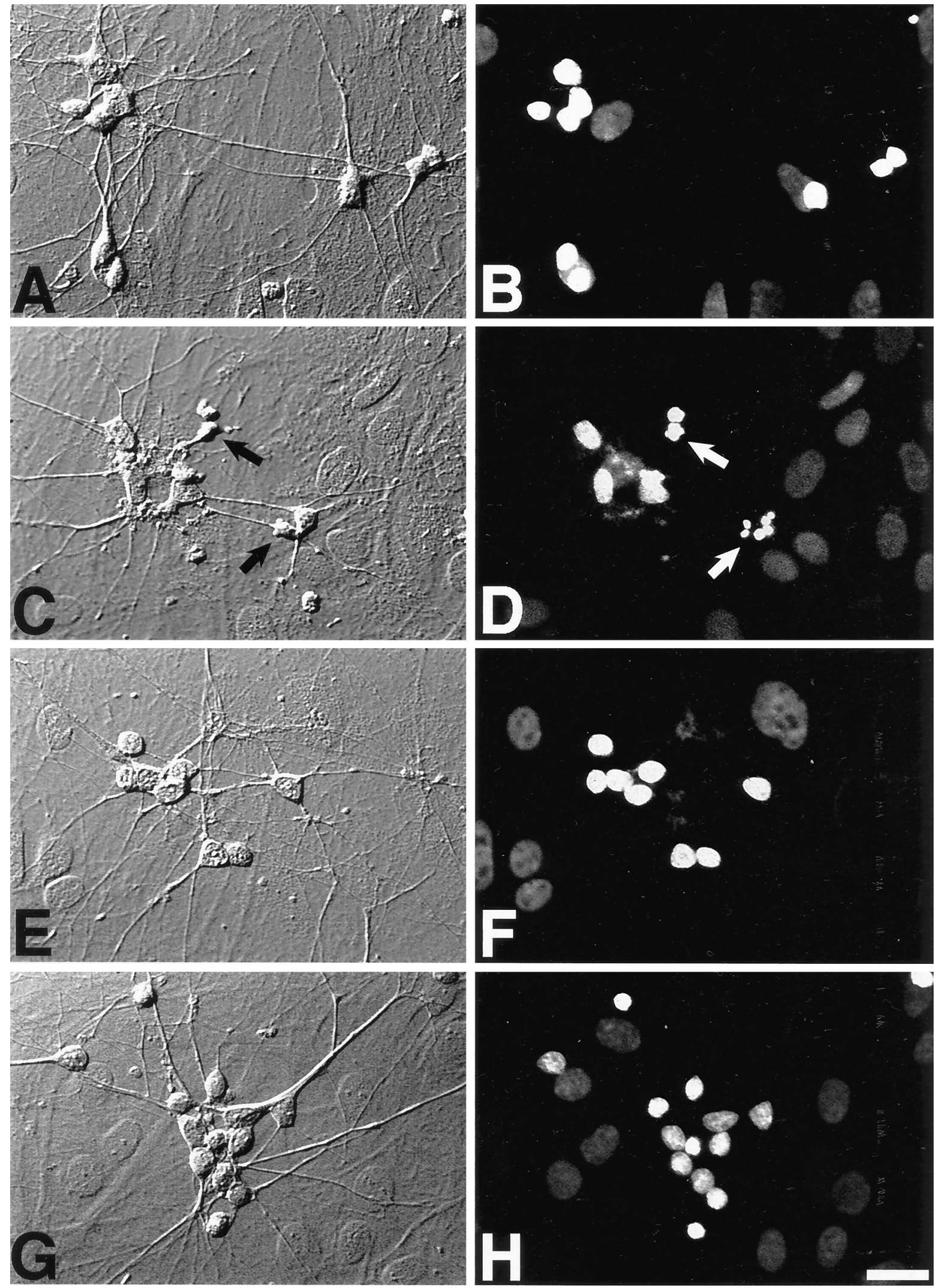

Figure 10. Inhibition of camptothecin-induced cortical neuronal apoptosis by flavopiridol and olomoucine. Mixed cultures were treated with $(C-H)$ or without $(A, B) 10 \mu \mathrm{M}$ camptothecin in the presence of no additional additives $(A-D), 0.5 \mu \mathrm{M}$ flavopiridol $(E, F)$, or $200 \mu \mathrm{M}$ olomoucine $(G, H)$ for 18 $\mathrm{hr}$. The cells were then fixed and stained with DAPI to visualize nuclear chromatin, and images were captured under differential interference contrast $(A, C, E, G)$ or fluorescence $(B, D, F, H)$ optics. Scale bar (shown in $H$ ), $20 \mu \mathrm{m}$. 
A

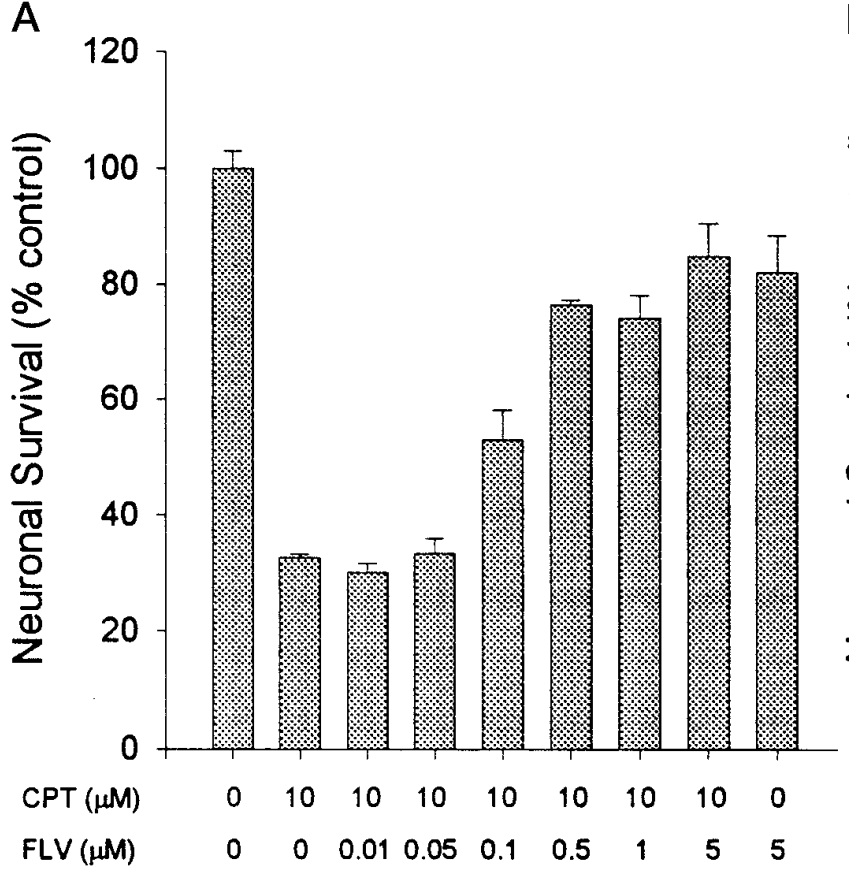

C

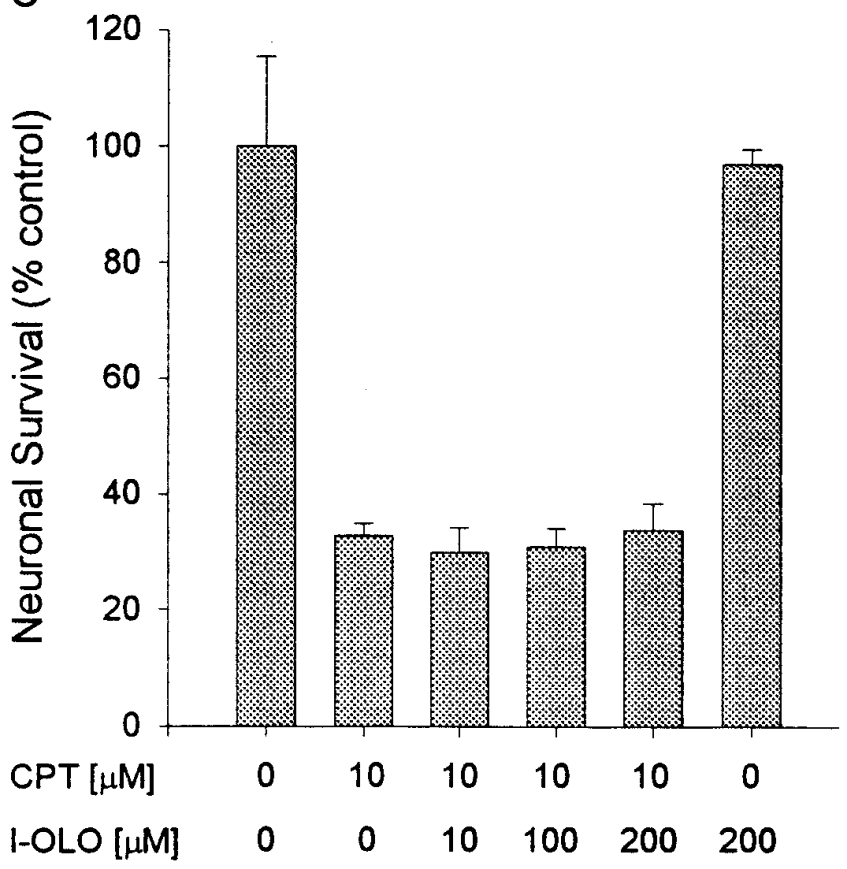

B

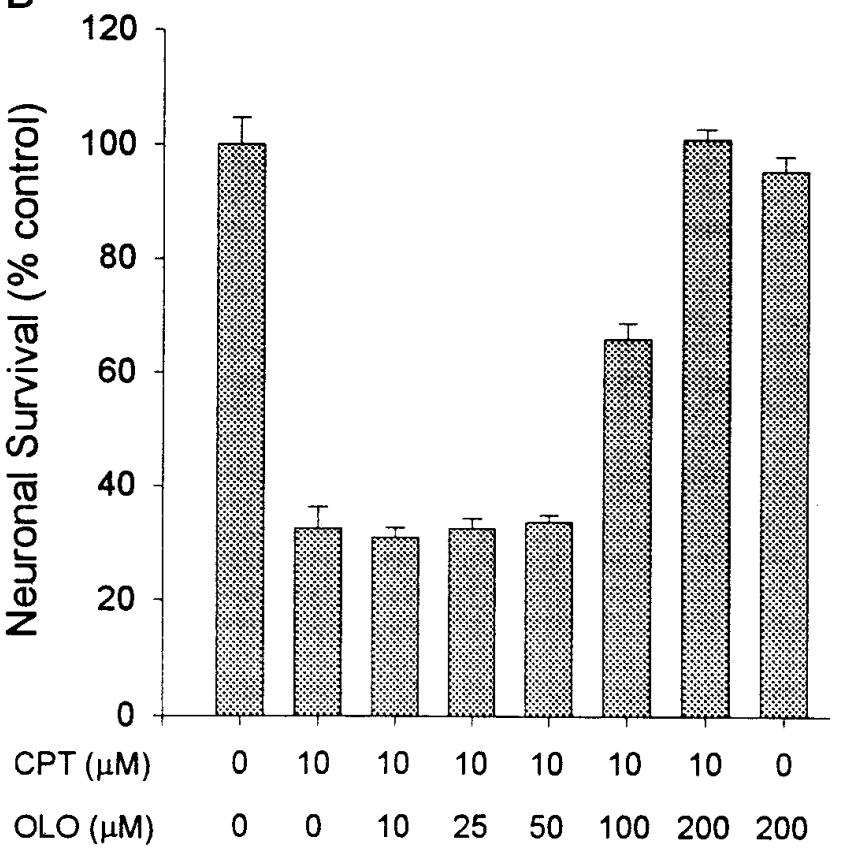

Figure 11. Dose-response relationships for inhibition of camptothecin-induced cortical neuronal death by flavopiridol and olomoucine. Mixed cultures were treated with or without $10 \mu \mathrm{M}$ camptothecin in the presence or absence of flavopiridol $(A)$, olomoucine $(B)$, or iso-olomoucine $(C)$, and neuronal survival was evaluated at $24 \mathrm{hr}$ by the CFDA assay. Data are expressed as percent control of the mean $\pm \mathrm{SD}$ ( $n=3-4$ per condition). The effects of both flavopiridol and olomoucine on neuronal survival were significant ( $p<0.0001$ by one-way ANOVA).

With respect to the induction of c-jun, this finding is particularly interesting, because this proto-oncogene has been shown to be necessary for cell death of sympathetic neurons (Estus et al., 1994; Ham et al., 1995). It is not known, however, whether a similar increase in c-jun levels is observed with camptothecin treatment in neurons.

Our findings may have clinical implications, in that neuropathies constitute a significant clinical side effect of the therapeutic administration of anticancer agents. As an example, some patients treated with high-dose araC for refractory leukemia develop a cerebellar toxicity syndrome, characterized by loss of Purkinje neurons (Winkelman and Hines, 1983; Vogel and Horoupian,

1993). In addition, patients treated with cis-platinum frequently develop peripheral neuropathies (Wallach et al., 1992; Mansfield and Castillo, 1994), and children treated with chemotherapy or radiotherapy for brain cancer show significant reductions in IQ (Radcliffe et al., 1994). Understanding the potential role of cell cycle deregulation in certain neuropathies may lead to clinical strategies that limit these side effects, perhaps through coadministration of neuroprotective agents like CDK inhibitors or G1/S blockers.

In summary, we have demonstrated that multiple agents with G1/S or CDK inhibitory activity prevent the death of neurons evoked by the topo-I inhibitor camptothecin. These results are 
consistent with the hypothesis that cell cycle signaling pathways have additional functions in the regulation of apoptosis in nondividing neurons after both trophic factor deprivation and DNA damage.

\section{REFERENCES}

Aller P, Rius C, Mata F, Zorrilla A, Cabanas C, Bellon T, Bernabeu C (1992) Camptothecin induces differentiation and stimulates the expression of differentiation-related genes in U-937 human promonocytic leukemia cells. Cancer Res 52:1245-1251.

Batistatou A, Greene LA (1993) Internucleosomal DNA cleavage and neuronal cell survival/death. J Cell Biol 122:523-532.

Brooks SF, Gibson LA, Rubin LL (1993) Apoptosis induced by NGFwithdrawal from differentiated PC12 cells involves activation of P34cdc2 kinase. Soc Neurosci Abstr 1:885.

Chen X, Bargonetti J, Prives C (1995) P53, through 21 (WAF/CIP1), induces cyclin D1 synthesis. Cancer Res 55:4257-4263.

Cheng B, Mattson MP (1991) NGF and bFGF protect rat hippocampal and human cortical neurons against hypoglycemic damage by stabilizing calcium homeostasis. Neuron 7:1031-1041.

D'Arpa P, Beardmore C, Liu LF (1990) Involvement of nucleic acid synthesis in cell killing mechanisms of topoisomerase poisons. Cancer Res 50:6919-6924.

Estus S, Zaks WJ, Freeman RS, Gruda M, Bravo R, Johnson EM (1994) Altered gene expression in neurons during programmed cell death: identification of c-jun as necessary for neuronal apoptosis. J Cell Biol 127:1717-1727.

Farinelli SE, Greene LA (1996) Cell cycle blockers mimosine, ciclopirox, and deferoxamine prevent the death of PC12 cells and postmitotic sympathetic neurons after removal of trophic support. J Neurosci 16:1150-1162.

Ferrari G, Greene LA (1994) Proliferative inhibition by dominantnegative Ras rescues naive and neuronally-differentiated PC12 cells from apoptotic death. EMBO J 13:5922-5928.

Ferrari G, Yan CYI, Greene LA (1995) N-acetylcysteine (D- and L-stereoisomers) prevents apoptotic death of neuronal cells. J Neurosci 15:2857-2866.

Filgueira de Azevedo W, Mueller-Dieckmann H-J, Schulze-Gahmen U, Worland PJ, Sausville E, Kim S-H (1996) Structural basis for specificity and potency of a flavanoid inhibitor of human CDK2, a cell cycle kinase. Proc Natl Acad Sci USA 93:2735-2740.

Freeman RF, Estus S, Johnson Jr EM (1994) Analysis of cell-related gene expression in postmitotic neurons: selective induction of cyclin D1 during programmed cell death. Neuron 12:343-355.

Ganeshaguru K, Hoffbrand AV, Grady RW, Cerami A (1980) Effects of various iron chelating agents on DNA synthesis in human cells. Biochem Pharmacol 29:1275-1279.

Gao CY, Zalenka PS (1995) Induction of cyclin B and H1 kinase activity in apoptotic PC12 cells. Exp Cell Res 219:612-618.

Greene LA, Tischler AS (1976) Establishment of a noradrenergic clonal line of rat adrenal pheochromocytoma cells which respond to nerve growth factor. Proc Natl Acad Sci USA 73:2424-2428.

Greene LA, Farinelli SE, Yan CYI, Ferrari G (1995) On the mechanisms by which neurotrophic factors regulate neuronal survival and cell death. In: Death in the nervous system (Ibanez CF, Fuxe K, Hokfelt T, Jornvall H, Olson L, Ottosen D, eds), pp 55-67. Oxford: Pergammon.

Ham J, Babji C, Whitfield J, Pfarr CM, Lallemand D, Yaniv M, Rubin LL (1995) A c-Jun dominant negative mutant protects sympathetic neurons against programmed cell death. Neuron 14:927-939.

Hoang AT, Cohen KJ, Barrett JF, Bergstrom DA, Dang CV (1994) Participation of cyclin A in Myc-induced apoptosis. Proc Natl Acad Sci USA 91:6875-6879.

Horwitz S, Chang C-K, Grollman AP (1971) Studies on camptothecin. I. Effects on nucleic acid and protein synthesis. Mol Pharmacol 7:632-644.

Hsiang YH, Hertzberg R, Hecht S, Liu LF (1985) Camptothecin induces protein-linked DNA breaks via mammalian DNA topoisomerase I. J Biol Chem 260:14873-14878.

Hsiang YH, Lihou MG, Liu LF (1989) Arrest of replication forks by drug-stabilized topoisomerase I-DNA cleavable complexes as a mechanism of cell killing by camptothecin. Cancer Res 49:5077-5082.

Kaur G, Stetler-Stevenson M, Sebers S, Worland P, Sedlacek H, Myers C, Czech J, Naik R, Sausville E (1992) Growth inhibition with reversible cell cycle arrest of carcinoma cells by flavone L86-8275. J Natl Cancer Inst 22:1736-1740.
Kharbanda S, Rubin E, Gunji H, Hinz H, Giovanella B, Pantazis P, Kufe D (1991) Camptothecin and its derivative induce expression of the c-jun protooncogene in human myeloid leukemia cells. Cancer Res 51:6636-6642.

Kontoghiorges GJ, Evans RW (1985) Site specificity of iron removal from transferrin by a-ketohydroxypyridine chelators. FEBS Lett 189:141-144.

Kranenburg O, van der Eb AJ, Zantema A (1996) Cyclin D1 is an essential mediator of apoptotic neuronal cell death. EMBO J 15:46-54.

Lee VM, Shelanski ML, Greene LA (1980) Characterization of antisera raised against cultured rat sympathetic neurons. Neuroscience 5:2239-2245.

Losiewitz MD, Carlson BA, Kaur G, Sausville EA, Worland PJ (1994) Potent inhibition of CDC2 kinase activity by the flavonoid L86-8275. Biochem Biophys Res Commun 201:589-595.

Mansfield SH, Castillo M (1994) MR of cis-platinum-induced optic neuritis. AJNR Am J Neuroradiol 15:1178-80.

Martin DP, Schmidt RE, DiStefano PS, Lowry OH, Carter JG, Johnson Jr EM (1988) Inhibitors of protein synthesis and RNA synthesis prevent neuronal death caused by nerve growth factor deprivation. J Cell Biol 106:829-844.

Martin DP, Wallace TL, Johnson Jr EM (1990) Cytosine arabinoside kills postmitotic neurons in a fashion resembling trophic factor deprivation: evidence that a deoxycytidine-dependent process may be required for nerve growth factor signal transduction. J Cell Biol 10:184-193.

McSheehy P, Gervasoni M, Lampasona V, Erba E, D'incalci M (1991) Studies of the differentiation properties of camptothecin in the human leukaemic cells K562. Eur J Cancer 27:1406-1411.

Meikrantz W, Schlegel R (1996) Suppression of apoptosis by dominant negative mutants of cyclin-dependent protein kinases. J Biol Chem 271:10205-10209.

Meikrantz W, Gisselbrecht S, Tam SW, Schlegel R (1994) Activation of cyclin A-dependent protein kinases during apoptosis. Proc Natl Acad Sci USA 91:3754-3758.

Mesner PW, Winters TR, Green SH (1992) Nerve growth factorwithdrawal induced cell death in neuronal PC12 cells resembles that in sympathetic neurons. J Cell Biol 119:1669-1680.

Morgan DO (1995) Principles of CDK regulation. Nature 374:131-134.

Morris EJ, Geller HM (1996) Induction of neuronal apoptosis by camptothecin, an inhibitor of DNA topoisomerase-I: evidence for cell-cycle independent toxicity. J Cell Biol 134:757-770.

Morrison RS, deVellis J (1981) Growth of purified astrocytes in a chemically defined medium. Proc Natl Acad Sci USA 78:7205-7209.

Nakajima M, Kashiwagi K, Ohta J, Furukawa S, Hayashi K, Kawashima T, Hayashi Y (1994) Etoposide induces programmed death in neurons cultured from the fetal rat central nervous system. Brain Res 641:350-352.

Oppenheim RW (1991) Cell death during development of the nervous system. Annu Rev Neurosci 14:453-501.

Pardee AB (1974) A restriction point for control of normal animal cell proliferation. Proc Natl Acad Sci USA 71:1286-1290.

Park DS, Farinelli SE, Greene LA (1996a) Inhibitors of cyclindependent kinases promote survival of post-mitotic neuronally differentiated PC12 cells and sympathetic neurons. J Biol Chem 271:8161-8170.

Park DS, Stefanis L, Farinelli SE, Yan CYI, Greene LA (1996b) Ordering the cell death pathway: differential effects of BCL2, an ICEfamily protease inhibitor, and other survival agents on JNK activation in serum/NGF deprived PC12 cells. J Biol Chem 271:21898-21906.

Petroski RE, Geller HM (1994) Selective labeling of embryonic neurons cultured on astrocyte monolayers with 5(6)-carboxyfluorescein diacetate (CFDA). J Neurosci Methods 52:23-32.

Ping Dou Q, An B, Yu C (1995) Activation of cyclin E-dependent kinase by DNA-damage signals during apoptosis. Biochem Biophys Res Commun 214:771-780.

Poluha W, Poluha DK, Chang B, Crosgie NE, Schonoff CM, Kilpatrick DL, Ross AH (1996) The cyclin-dependent kinase inhibitor p21waf1 is required for survival of differentiating neuroblastoma cells. Mol Cell Biol 16:1334-1341.

Radcliffe J, Brunin GR, Sutton LN, Goldwein JW, Phillips PC (1994) Cognitive deficits in long-term survivors of childhood medulloblastoma and other noncortical tumors: age-dependent effects of whole brain radiation. Int J Dev Neurosci 12:327-334. 
Rubin LL, Philpott KL, Brooks SF (1993) The cell cycle and cell death. Curr Biol 3:391-394.

Rukenstein A, Rydel RE, Greene LA (1991) Multiple agents rescue PC12 cells from serum-free cell death by translation- and transcriptionindependent mechanisms. J Neurosci 11:2552-2563.

Rydel RE, Greene LA (1988) cAMP analogs promote survival and neurite outgrowth in cultures of rat sympathetic and sensory neurons independently of nerve growth factor. Proc Natl Acad Sci USA 85:1257-1261.

Shimizu T, O'Connor PM, Kohn KW, Pommier Y (1995) Unscheduled activation of cyclin B1/Cdc2 kinase in human promyelocytic leukemia cell line HL60 cells undergoing apoptosis induced by DNA damage. Cancer Res 55:228-231.

Tomkins CE, Edwards SN, Tolkovsky AM (1994) Apoptosis is induced in post-mitotic rat sympathetic neurons by arabinosides and topoisomerase II inhibitors in the presence of NGF. J Cell Sci 107:1499-1507.

Troy CM, Shelanski ML (1994) Down-regulation of copper/zinc superoxide dismutase causes apoptotic death in PC12 neuronal cells. Proc Natl Acad Sci USA 91:6384-6387.

Troy CM, Stefanis L, Prochiantz A, Greene LA, Shelanski ML (1996) The contrasting roles of ICE family protease and interleuken-1-B in apoptosis induced by trophic factor withdrawal and by copper/zinc superoxide dismutase down-regulation. Proc Natl Acad Sci USA 93:5635-5640.
Ventimiglia R, Geller HM (1987) Cell types and cell-substrate interactions in serum-free dissociated cultures of rat hypothalamus. Brain Res 436:339-351.

Vesely J, Havlicek L, Strand M, Blow JJ, Donella-Deanna A, Pinna L, Letham DS, Kato J, Detivaud L, Leclerc S, Mieijer L (1994) Inhibition of cyclin-dependent kinases by purine analogues. Eur J Biochem 224:771-786.

Vogel H, Horoupian DS (1993) Filamentous degeneration of neurons. A possible feature of cytosine arabinoside neurotoxicity. Cancer 71:1303-1308.

Wallace TL, Johnson Jr EM (1989) Cytosine arabinoside kills postmitotic neurons: evidence that deoxycytidine may have a role in neuronal survival that is independent of DNA synthesis. J Cell Biol 9:115-124.

Wallach PM, Love SR, Fiorica JV, Hoffman MS, Flannery MT (1992) Erythromycin associated hearing loss in a patient with prior cisplatinum induced ototoxicity. J Fla Med Assoc 79:821-822.

Winkelman MD, Hines JD (1983) Cerebellar degeneration caused by high -dose cytosine arabinoside: a clinicopathological study. Ann Neurol 14:520-527.

Yan CYI, Ferrari G, Greene LA (1995) $N$-acetylcysteine-promoted survival of $\mathrm{PC} 12$ cells is glutathione-independent but transcriptiondependent. J Biol Chem 270:26827-26832. 